\title{
Of Promises and Discontents: Mapping India's Response to Guaranteeing the Right to Mental Health during the Covid-19 Pandemic
}

\author{
Sanskriti SANGHI ${ }^{*}$ (D) and Raushan Tara JASWAL ${ }^{* *}$ \\ Jindal Global Law School, O.P. Jindal Global University, Sonipat, Haryana, India \\ Corresponding author: Sanskriti SANGHI, Email: ssanghi@jgu.edu.in
}

(Received 11 January 2021; revised 13 August 2021; accepted 8 September 2021;

first published online 15 December 2021)

\begin{abstract}
As of 2020, close to 1 billion people are living with mental disorders. The COVID-19 pandemic has revealed and intensified the shortcomings in guaranteeing the right to mental health, particularly of the marginalized. The article discusses the international human rights framework with the endeavour of highlighting the non-derogability of the right and the obligations imposed on States in pursuance of it. By discussing the Indian experience the article exemplifies that, despite greater normative clarity, practice has not been brought into conformity in most States, resulting in pre-existing lacunae being amplified during the pandemic. The article proceeds to outline recommendations for States to consider by treating India as a global reference. The overarching conclusion is that while the pandemic has made it even more apparent that the implementation of the rightsframework is deficient, it has also provided an opportunity to advance which can only be availed by operationalizing this framework.
\end{abstract}

Keywords: Mental health; Human rights; India; COVID-19; Migrant workers; Healthcare workers.

"I feel we need to stop seeing mental and physical health as either/or and more as a both/and situation. There is no difference. We are mental. We are physical. We are not split up into unrelated sections. We are not an existential department store. We are everything at once."

—Matt Haig, Notes on a Nervous Planet ${ }^{1}$

Mental health, though commonly mischaracterized as a medical concern, is a matter of human rights. The international human rights framework ("rights-framework"), through norms and standards gradually embedded in international treaties, global

\footnotetext{
* B.A. LL.B. (H) (Gujarat National Law University); LL.M. (International Law) (University of Cambridge). Lecturer in Law, Jindal Global Law School, O.P. Jindal Global University, Sonipat, Haryana, India.

** Advocate (India). B.A. LL.B. (H) (Amity Law School, Delhi); LL.M. (International Law) (University of Cambridge). Lecturer in Law, Jindal Global Law School, O.P. Jindal Global University, Sonipat, Haryana, India.

${ }^{1}$ Matt Haig, Notes on a Nervous Planet (Edinburgh: Canongate Books Ltd., 2018).

(c) The Author(s), 2021. Published by Cambridge University Press. This is an Open Access article, distributed under the terms of the Creative Commons Attribution licence (https://creativecommons.org/licenses/by/4.0/), which permits unrestricted re-use, distribution, and reproduction in any medium, provided the original work is properly cited.
} 
commitments, and authoritative guidance issued by human rights bodies, has made this interconnection between mental health and human rights abundantly clear. Not only has it explicitly recognized the interdependence between mental health and physical health as well as the dependence of mental health on an array of supports enshrined in other human rights, it has also consciously attempted to ensure that due attention is paid to serious as well as common mental disorders. The endeavour of the rights-framework has been to prevent hierarchization from being used to justify non-realization of the right to mental health but, rather, promote the "whole person" approach. Beyond establishing foundational standards at the international level, the rights-framework has also imposed obligations on States to create, implement, and monitor legislative as well as other measures, initiate processes, and establish mechanisms to guarantee the right to mental health in a non-discriminatory manner at the domestic level.

While greater clarity has been achieved about the contours of the right to mental health, and its progressive interpretation in nexus with other human rights, which form part of the extensive and constantly evolving rights-framework, there have been massive challenges in bringing practice into conformity at the domestic level. The failure of States to recognize and prioritize mental health as a human right has resulted in the negation of equal protection for persons grappling with mental health conditions, negligence in attending to the underlying determinants causative of poor mental health, continued investment (if any) in a reductionist biomedical model, and insufficient focus on training and removal of attitudinal barriers to integration. Against this backdrop, and with its near-exclusive focus on physical health and objectives of public safety, the COVID-19 pandemic ("the pandemic") has exposed the fault lines in the implementation of the framework guaranteeing the right to mental health more than ever before. By mapping India's response to guaranteeing the right to mental health during the pandemic, this article seeks to showcase the ways in which the pandemic has exposed and deepened these deficiencies in the regulatory frameworks and mental healthcare systems, particularly for the vulnerable and marginalized. It argues that, instead of being reflective of an irredeemable disaster, the deficiencies laid bare by the pandemic are a call to action for operationalizing the rights-framework towards improved efforts for the realization of the right to mental health.

This article has been divided into five parts. Part I traces the growing prominence of the right to mental health in the international fora as a result of the progressive interpretation of the right to health, and the emergence of disability-specific human rights instruments. Part II analyses the facets of the right to mental health that are nonderogable, endeavouring to establish States' obligations to realize the right as being continuous, regardless of the pandemic. Part III draws on the Indian experience to showcase the manner in which the pandemic has laid bare the shortcomings in guaranteeing the right to mental health. By delving into the conditions of healthcare/frontline workers and migrant workers as case-studies, this segment illustrates how pre-existing concerns about the fulfilment of the right have amplified during the pandemic, particularly for the vulnerable and marginalized sections of Indian society. The authors conclude this segment by proposing certain recommendations, which India is urged to implement in order to harmonize its regulatory framework with the international human rights framework. Part IV treats the Indian experience as a core global reference for the pivotal role human rights can and should play in policy making at the domestic level. It proceeds to outline certain recommendations for States to consider effectuating in order to guarantee the right to mental health amidst, as well as in, the aftermath of the COVID-19 pandemic. Part V concludes the article, urging the realization rather than the dismissal of the promise of human rights. 


\section{International Recognition for the Right to Mental Health}

The prominence of mental health as a human rights concern has been growing steadily in international fora. The transition from being viewed as a medical concern requiring a cure to its reclassification as a human rights concern can be attributed to the evolutive capacity for normative expansion and practical application ${ }^{2}$ at the heart of the global human rights framework, as well as to the growing interest among the international community to guarantee individuals "good mental health". ${ }^{3}$ The gradual acknowledgement of mental health as a human rights concern has led to the formal recognition of the applicability of the "respect-protect-fulfil" framework to persons with mental health conditions. While, in theory, human rights are universal in their coverage and are not dependent on government benevolence, such explicit recognition has inaugurated the space for the "discussions and related actions [to be] rights-based, holistic and rooted in the lived experience of those left furthest behind by harmful sociopolitical systems, institutions and practices". In this part, the authors trace the expanded standard-setting with respect to persons with mental health conditions, situating this process along a continuum of several pivotal developments in the international rights-framework. Broadly, these developments have been classified into two: the progressive interpretation of the right to health, and the emergence of disability-specific human rights instruments.

\section{A. The Progressive Interpretation of the Right to Health}

The international human rights framework was inaugurated by the Universal Declaration of Human Rights (UDHR), which was adopted by the United Nations General Assembly (UNGA) on the 10th of December 1948 as a non-binding "common standard of achievement for all peoples and all nations". ${ }^{5}$ While the UDHR makes no express reference to mental health, the general language of Article 25, which recognizes "the right to a standard of living adequate for health and well-being", 6 allows us to draw a relevant connection between mental health and human rights. ${ }^{7}$ Furthermore, the social model of health embodied by the UDHR has influenced the subsequent normative expansion of the right to health as inclusive of the right to mental health. ${ }^{8}$ Notable among these is the International Covenant on Economic, Social and Cultural Rights (ICESCR), which guarantees under Article 12 "the right of everyone to the enjoyment of the highest attainable

\footnotetext{
${ }^{2}$ Michael L. PERLIN and Éva SZELI, "Mental Health Law and Human Rights: Evolution and Contemporary Challenges" in Michael DUDLEY, Derrick SILOVE, and Fran GALE, eds., Mental Health and Human Rights: Vision, Praxis, and Courage (Oxford: Oxford University Press, 2012), 80 at 82.

${ }^{3}$ Office of the United Nations High Commissioner for Human Rights (OHCHR), "The Right to Mental Health", online: OHCHR <https://www.ohchr.org/EN/Issues/Health/Pages/RighttoMentalHealth.aspx>. "Good mental health" is a term which has been postured as encompassing "much more than the absence of a mental impairment".

${ }^{4}$ Right of Everyone to the Enjoyment of the Highest Attainable Standard of Physical and Mental Health, Report of the Special Rapporteur on the Right of Everyone to the Enjoyment of the Highest Attainable Standard of Physical and Mental Health, UN Doc. A/HRC/44/48 (2020), at para. 3.

${ }^{5}$ Universal Declaration of Human Rights, GA Res. 217 (III), UN Doc. A/810 (1948), Preamble [UDHR].

${ }^{6}$ Ibid., art. 25.

${ }^{7}$ Comfort ASANBE, Ayorkor GABA, and Jeea YANG, "Mental Health is a Human Right: APA-UN Representatives Highlight Mental Health's Important Place in the UN's Universal Declaration of Human Rights” Psychology International (December 2018), online: American Psychological Association <https://www.apa.org/international/ pi/2018/12/mental-health-rights>.

${ }^{8}$ Stephen P. MARKS, Lena VERDELI, and Sandra WILLIS, "Mental Health and Human Rights" in Neal S. RUBIN and Roseanne L. FLORES, eds., The Cambridge Handbook of Psychology and Human Rights (Cambridge: Cambridge University Press, 2020), 183 at 187.
} 
standard of physical and mental health", ${ }^{9}$ and outlines the steps to be taken by States for the realization of that right.

The authoritative guidance contained within General Comments 5 (1994) and 14 (2000), adopted by the Committee on Economic, Social and Cultural Rights (CESCR), has played a key role in clarifying and operationalizing this provision. As early as 1994, Article 12 was interpreted as being applicable to persons with mental disabilities, ${ }^{10}$ wherein the term "disability" was understood to mean "a great number of different functional limitations occurring in any population ... People may be disabled by physical, intellectual or sensory impairment, medical conditions or mental illness. Such impairments, conditions or illnesses may be permanent or transitory in nature". ${ }^{11}$ In 2000 , Article 12 was also interpreted as encompassing the underlying determinants of health, alongside the right to timely and appropriate healthcare, ${ }^{12}$ thereby drawing key interlinkages between the right to mental health and other rights guaranteed by the International Covenant on Civil and Political Rights ${ }^{13}$ and the ICESCR. ${ }^{14}$

Article 12 of the ICESCR has further been interpreted progressively in favour of a nonderogable right to mental health in the recent report of the United Nations High Commissioner for Human Rights on Mental Health and Human Rights (2017), requested pursuant to Resolution 32/18, ${ }^{15}$ as adopted by the Human Rights Council (HRC). The Report criticized the hierarchical prioritization accorded by States to physical health over mental health, ${ }^{16}$ leading to inadequate resources being allocated to mental health, as well as to inefficient decisions about the use of the resources. ${ }^{17}$ The Report added that not only do such actions "undermine the availability, acceptability, accessibility and quality of mental health services", ${ }^{18}$ they also contravene the requirements ${ }^{19}$ of Article 2(1) of the ICESCR to fulfil the minimum essential levels of the right to mental health, ${ }^{20}$ and to employ maximum available resources for the progressive realization of the right to health. ${ }^{21}$ In its recommendations, it urged States to create an enabling legal and policy environment, to allocate resources optimally, to ensure participation of affected communities, to establish a mechanism for accountability, and to collect disaggregated data. ${ }^{22}$

While the progressive interpretation of the ICESCR's legally binding framework for the highest attainable standard of health has been crucial to the applicability of the

\footnotetext{
${ }^{9}$ International Covenant on Economic, Social and Cultural Rights, 16 December 1966, 993 U.N.T.S. 3, 6 I.L.M. 360 (entered into force 3 January 1976), art. 12 [ICESCR].

${ }^{10}$ Committee on Economic, Social and Cultural Rights, General Comment No. 5: Persons with Disabilities, 9 December 1994, UN Doc. E/1995/22 (1994), at para. 34.

${ }^{11}$ Ibid., at para. 3.

${ }^{12}$ Committee on Economic, Social and Cultural Rights, General Comment No. 14: The Right to the Highest Attainable Standard of Health (Art. 12), 11 August 2000, UN Doc. E/C.12/2000/4 (2000), at para. 11.

${ }^{13}$ International Covenant on Civil and Political Rights, 19 December 1966, 999 U.N.T.S. 171, 6 I.L.M. 368 (entered into force 23 March 1976).

${ }^{14}$ Ibid., at para. 3; Human Rights Watch, "Human Rights Dimensions of COVID-19 Response" (19 March 2020), online: Human Rights Watch <https://www.hrw.org/news/2020/03/19/human-rights-dimensions-covid-19response>.

${ }^{15}$ Mental Health and Human Rights, 1 July 2016, HRC Res. 32/18, UN Doc. A/HRC/RES/32/18 (2016).

${ }^{16}$ Mental Health and Human Rights, Report of the United Nations High Commissioner for Human Rights, 31 January 2017, UN Doc. A/HRC/34/32 (2017), at para. 21.

${ }^{17}$ Ibid., at para. 19.

${ }^{18}$ Ibid.

${ }^{19}$ Committee on Economic, Social and Cultural Rights, General Comment No. 3: The Nature of States Parties' Obligations (Art. 2, Para. 1, of the Covenant), 14 December 1990, UN Doc. E/1991/23 (1990), at para. 10.

${ }^{20}$ Mental Health and Human Rights, 28 September 2017, HRC Res. 36/13, UN Doc. A/HRC/RES/36/13 (2017), at para. 8 .

${ }^{21}$ UN Doc. A/HRC/34/32 (2017), supra note 16 at para. 19.

${ }^{22}$ Ibid., at paras. $36-50$.
} 
"respect-protect-fulfil" framework of human rights to mental health, the conjunctive establishment of complementary standards in other international and regional treaties, global commitments to human rights, and guidance issued by the Special Rapporteurs on Health has also played a pivotal role. Other than in the Convention on the Rights of Persons with Disabilities (UNCRPD), which is discussed in Part I, B of this article, the right to mental health is covered, explicitly or implicitly, in the Convention on the Rights of the Child (arts. 17, 19, 23, 24, 25, 27, 29, and 32), in the Convention on the Elimination of All Forms of Discrimination Against Women (arts. 10(h), 11(1)(f), 11(2), 12, and 14(2) (b)), and in the Declaration on the Rights of Indigenous People (art. 24).

The regional human rights treaties, much like the global human rights framework, treat the right to health as a long-term programmatic goal ${ }^{23}$ and tend to include the right to mental health within their provisions guaranteeing the right to health. This is exemplified by the provisions guaranteeing the right to health in the Additional Protocol to the American Convention on Human Rights in the Area of Economic, Social and Cultural Rights (art. 10), the African Charter on Human and Peoples' Rights (art. 16), the African Charter on the Rights and Welfare of the Child (art. 14), and the Arab Charter on Human Rights (art. 39). Regional human rights courts have also displayed the inclination to address cases pertaining to mental health, ${ }^{24}$ showcasing its integral relationship with human rights. The formal legal framework outlined thus far has also been complemented by a recognition of the challenge posed by mental illnesses to sustainable development in the 2030 Agenda for Sustainable Development Goals (SDGs), which reflects a commitment to the prevention and treatment of non-communicable diseases, including behavioural, developmental, and neurological disorders. ${ }^{25}$ Goal 3 of the SDGs expresses a commitment to "ensure healthy lives and promote the well-being for all at all ages", ${ }^{26}$ with Target 3.4 specifically referencing the promotion of mental health and well-being, and Target 3.8 emphasizing issues of clear relevance to mental health within universal health coverage. ${ }^{27}$ Pivotally, beyond such explicit recognition in Goal 3 , mental health is a cross-cutting issue that shares strong interdependencies with several other global goals, thereby necessitating an emphasis on it in efforts exerted towards achieving these goals. ${ }^{28}$

\footnotetext{
${ }^{23}$ Asanbe, Gaba, and Yang, supra note 7.

${ }^{24}$ Winterwerp v. The Netherlands (Application no. 6301/73) [1979] ECHR 4, (1979-80) 2 EHRR 387; Victor Rosario Congo v. Ecuador [1999] Case No. 11.427, INTER-AM. C.H.R. 63/99; Purohit and Moore v. The Gambia [2003] Comm. No. 241/2001, 16th Activity Report of the Afr. C.H.P.R.

${ }^{25}$ Transforming Our World: The 2030 Agenda for Sustainable Development, 25 September 2015, GA Res. 70/1, UN Doc. A/RES/70/1 (2015), Goal 26. See also: Nicole VOTRUBA and Graham THORNICROFT, "Sustainable Development Goals and Mental Health: Learnings from the Contribution of the FundaMentalSDG Global Initiative" (2016) 3 Global Mental Health E26, online: Cambridge University Press <https://doi.org/10.1017/gmh.2016.20>.

${ }^{26}$ Transforming Our World, supra note 25 at Goal 3.

${ }^{27}$ Ibid., at Goals 3.4 and 3.8; Report of the Special Rapporteur on the Right of Everyone to the Enjoyment of the Highest Attainable Standard of Physical and Mental Health, UN Doc. A/HRC/35/21 (2017), para. 10; Asanbe, Gaba, and Yang, supra note 7.

${ }^{28}$ Nicole VOTRUBA, Julian EATON, Martin PRINCE, and Graham THORNICROFT, "The Importance of Global Mental Health for the Sustainable Development Goals" (2014) 23 Journal of Mental Health 283; Ragnhild DYBDAHL and Lars LIEN, "Mental Health is an Integral Part of the Sustainable Development Goals" (2017) 1 Preventive Medicine and Community Health 1. See also for synergies between the aspirational goals formulated within the SDGs and key social determinants of mental disorders, Crick LUND, Carrie BROOKE-SUMNER, Florence BAINGANA, Emily CLAIRE-BARON, Erica BREUER, Prabha CHANDRA, Johannes HAUSHOFER, Helen HERRMAN, Mark JORDANS, Christian KIELING, Maria ELENA MEDINA-MORA, Ellen MORGAN, Olayinka OMIGBODUM, Wietse TOL, Vikram PATEL, and Shekhar SAXENA, "Social Determinants of Mental Disorders and the Sustainable Development Goals: A Systematic Review of Reviews” (2018) 5(4) Lancet Psychiatry 357, online: Johannes Haushofer: <https://haushofer.ne.su.se/publications/Lund_et_al_LancetPsychiatry_2018.pdf>.
} 
Such interdependence of human rights and mental health, ${ }^{29}$ as well as the vulnerability and marginalization of persons with mental disabilities, ${ }^{30}$ has further been emphasized by the Special Rapporteurs on the Right to Health, from the very first year of their mandate (2003). In 2017, Dainius Pūras, the then Special Rapporteur on the Right to Health, amplified this call for a human rights-based approach to mental health. ${ }^{31}$ In the seminal 2017 Report, he rejected the "reductionist biomedical paradigm" 32 perpetuated by the dominance of the biomedical model, power asymmetries, and the biased use of evidence in mental health research. ${ }^{33}$ He also attempted to tether the understanding of the right to mental health in the obligations emanating from the core human rights treaties: nondiscrimination, participation, international cooperation and assistance, accountability and remedial measures, informed consent and non-coercion, and addressing of underlying

\footnotetext{
${ }^{29}$ The Right of Everyone to the Enjoyment of the Highest Attainable Standard of Physical and Mental Health, Report of the Special Rapporteur, Paul Hunt, Submitted in Accordance with Commission Resolution 2002/3, 13 February 2003, UN Doc. E/CN.4/2003/58 (2003), at 15, para. 59.

${ }^{30}$ Report of the Special Rapporteur on the Right of Everyone to the Enjoyment of the Highest Attainable Standard of Physical and Mental Health, Paul Hunt, 11 February 2005, UN Doc. E/CN.4/2005/51 (2005), at 2, Summary, 7-8, paras. 19-22. In particular, the definition of "mental disability" employed by the Report bears attention (paras. 18-20):
}

In this report the umbrella term "mental disability" includes major mental illness and psychiatric disorders, e.g., schizophrenia and bipolar disorder; more minor mental ill health and disorders, often called psychosocial problems, e.g., mild anxiety disorders; and intellectual disabilities, e.g., limitations caused by, among others, Down's syndrome and other chromosomal abnormalities, brain damage before, during, or after birth, and malnutrition during early childhood. "Disability" refers to a range of impairments, activity limitations, and participation restrictions, whether permanent or transitory. Accordingly, the Special Rapporteur uses the term mental disability when referring to the right-to-health entitlements and freedoms of common concern to, as well as abuses often experienced by, persons with all types of mental disability.

Further, the recognition of mental health as a central element of the right to health for all should also be noted (para. 22):

Moreover, the right to mental health is not simply a concern of persons with mental disabilities, but also the population more generally. Mental health is a central element of good health and the right to mental health is a central element of the right to health for all.

${ }^{31}$ UN Doc. A/HRC/35/21 (2017), supra note 27 at paras. 4-5. The recognition of all persons as rights-holders with respect to mental health and well-being, as enshrined in this 2017 Report, is pivotal for the manner in which responses to guaranteeing this right are framed by States amidst as well as in the aftermath of the pandemic. The Special Rapporteur notes (paras. 4-5):

Everyone, throughout their lifetime, requires an environment that supports their mental health and wellbeing; in that connection, we are all potential users of mental health services. Many will experience occasional and short-lived psychosocial difficulties or distress that require additional support. Some have cognitive, intellectual, and psychosocial disabilities, or are persons with autism who, regardless of self-identification or diagnosis, face barriers in the exercise of their rights on the basis of a real or perceived impairment and are, therefore, disproportionately exposed to human rights violations in mental health settings. Many may have a diagnosis related to mental health or identify with the term, while others may choose to identify themselves in other ways, including as survivors. The present report distinguishes between users of services and persons with disabilities, based on the barriers faced by the latter, considering in an inclusive manner that everyone is a rights holder.

${ }^{32}$ Ibid., para. 8.

${ }^{33}$ Ibid., paras. 16-29. 
social determinants, towards a framework of care and support. ${ }^{34}$ A key impact of the Report has been Resolution 36/13, adopted by the HRC on 28 September 2017, in which States have been urged to integrate human rights and mental healthcare. ${ }^{35}$ In his final report to the HRC in 2020, Püras reaffirmed the importance of "rights-based mental health praxis". ${ }^{36}$ While dwelling on the increasing prominence of mental health as a global goal, he urged the international community to endeavour to understand mental health better, and to engage in further conversations about ways to respond to challenges posed by it at the global, regional, and domestic levels. ${ }^{37}$

The process of charting the progressive interpretation of the right to health would be incomplete without tracking the contribution of the World Health Organization (WHO). Influenced by the same social model of health as undergirding and pervading the $\mathrm{UDHR}^{38}$ the WHO attempted to expand the notion of health "from mere absence of disease to well-being rooted in the person's social ecology"39 from as early as 1946 onwards. This is exemplified by the Preamble of the WHO Constitution, which defines health as "a state of complete physical, mental and social well-being and not merely the absence of disease or infirmity", ${ }^{40}$ while affirming the nature of the "enjoyment of the highest attainable standard of health" ${ }^{41}$ as a fundamental right for all without discrimination. It is the holistic nature of this approach to health that has enabled the WHO to embed a human rights-based approach to mental health, as well as draw out the inextricable linkages between the rights in a person's ecology across its body of work. In its report titled Mental Health: New Understanding, New Hope (2001), ${ }^{42}$ for instance, the WHO reinforced its efforts towards a public health framework cognizant and capable of mainstreaming human rights in medical care.

The Mental Health Action Plan 2013-2020, adopted by the Sixty-fifth World Health Assembly in 2012, and the QualityRights Tool Kit developed by the WHO, have both been turning points for a human rights-based approach to mental health. The Action Plan defines mental health as a "state of well-being in which the individual realizes his or her own abilities, can cope with the normal stresses of life, can work productively and fruitfully, and is able to make a contribution to her or his community", ${ }^{3}$ recognizing the dependence of mental health and well-being on several other human rights, as well as an array of resources and supports. ${ }^{44}$ Further, the Action Plan situates strategies, actions, and interventions in mental health within the international human rights framework by requiring their compliance with the legal standards established by them, ${ }^{45}$

\footnotetext{
${ }^{34}$ Ibid., paras. $35-6$.

${ }^{35}$ UN Doc. A/HRC/RES/36/13 (2017), supra note 20.

${ }^{36}$ UN Doc. A/HRC/44/48 (2020), supra note 4 at para. 3.

${ }^{37}$ Ibid.

${ }^{38}$ Marks, Verdeli, and Willis, supra note 8 at 186.

${ }^{39}$ Ibid., at 187.

${ }^{40}$ Constitution of the World Health Organization, 22 July 1946, 14 U.N.T.S. 185 (entered into force 7 April 1948), Preamble.

41 Ibid.

${ }^{42}$ World Health Organization (WHO), The World Health Report 2001: Mental Health: New Understanding, New Hope (Geneva: World Health Organization, 2001), online: WHO <https://apps.who.int/iris/bitstream/handle/10665/ 42390/WHR_2001.pdf?sequence=1\&isAllowed=y>.

${ }^{43}$ WHO, Mental Health Action Plan 2013-2020 (Geneva: World Health Organization, 2013) at 6, online: WHO <https://apps.who.int/iris/bitstream/handle/10665/89966/9789241506021_eng.pdf;jsessionid=5F48AEF8531151 AAE6A92FC177B7F716? sequence=1>.

${ }^{44}$ Sebastian Porsdam MANN, Valerie J. BRADLEY, and Barbara J. SAHAKIAN, "Human Rights-Based Approaches to Mental Health: A Review of Programs" (2016) 18 Health and Human Rights Journal 263.

${ }^{45}$ Mental Health Action Plan 2013-2020, supra note 43 at 10.
} 
thereby knitting together the expansionary interpretations and interlinkages of the right to health, disability-specific standards, and the Action Plan urging outcomes-based progress in mental health. The QualityRights Tool Kit, ${ }^{46}$ recommended by the Special Rapporteur on Health, ${ }^{47}$ complements these efforts by providing practical guidance to States on the human rights standards to be adhered to in mental health facilities, as well as methods for assessing and improving the quality of care.

The progressively evolving interpretation of the right to the highest attainable standard of health through the increasing involvement of human rights authorities has been significant in enabling States to fully realize the right to mental health for all. In the context of mental health, such developments in the rights-framework are particularly significant as they attach formal and express legal protections to a right hitherto ignored, as well as legitimize international scrutiny of domestic health policies and practices which implicate that right. ${ }^{48}$ Such developments also persistently reiterate the inextricable linkages between mental health and a wide array of other human rights, thereby situating the right to mental health within a network of interconnected rights likely to also be implicated by violations of the right to mental health in contravention of the States' international obligations. However, despite these developments within the rights-framework, a need was felt for the introduction of a human rights instrument that employed language specific to persons with mental disabilities, ${ }^{49}$ and which explicitly recognized persons with disabilities as a separate protected category within its equality clauses. ${ }^{50}$ The adoption of the UNCRPD in 2006, endeavoured to occupy this space, and to embed the distinction between impairment and the experience of being disabled due to systems that discriminated between the two. As Mills notes, "[t]his difference is more than semantic: it is a distinction in causal attribution which has material effects in directing focus to where transformation is most needed" ${ }^{51}$ and in the context of mental health, this distinction reinforces the idea that "mental distress may operate as an impairment in that a person feels, and/or is made to feel, unable to live a life of value to them". ${ }^{52}$

\section{B. The Emergence of Disability-Specific Human Rights Instruments}

The insufficiency of the "generic recognition of human rights for all" ${ }^{3}$ to address the rights violations, or to dismantle the attitudinal barriers experienced by persons with disabilities, led to advocacy for the express codification of the rights of persons with

\footnotetext{
${ }^{46}$ WHO, WHO QualityRights Tool Kit: Assessing and Improving Quality and Human Rights in Mental Health and Social Care Facilities (Geneva: World Health Organization, 2012), online: WHO <https://apps.who.int/iris/bitstream/handle/10665/70927/9789241548410_eng.pdf?sequence=3>.

${ }^{47}$ UN Doc. A/HRC/35/21 (2017), supra note 27 at para. 95.

${ }^{48}$ Carla A. Arena VENTURA, "International Law, Mental Health and Human Rights", Center for Civil and Human Rights, University of Notre Dame, June 2014, at 1.

49 Ibid., at 2.

${ }^{50}$ Theresia DEGENER, "International Disability Law - A New Legal Subject on the Rise: The Interregional Experts' Meeting in Hong Kong, 13-17 December 1999” (2000) 18 Berkeley Journal of International Law 180 at 187; Jasmine CAMERON, “Mental Health Law: International Legal Standards and Human Rights” Legal Dialogue (16 October 2017), online: Legal Dialogue <https://legal-dialogue.org/mental-health-law>.

${ }^{51}$ China MILLS, “From 'Invisible Problem' to Global Priority: The Inclusion of Mental Health in the Sustainable Development Goals” (2018) 49(3) Development and Change 843.

52 Ibid.

${ }^{53}$ Piers GOODING, A New Era for Mental Health Law and Policy: Supported Decision-Making and the UN Convention on the Rights of Persons with Disabilities (Cambridge: Cambridge University Press, 2017) at 42, citing Clarence J. SUNDRAM, "A Discussion of Legal Capacity in the Draft Convention on Disability", National Disability Authority, Ireland, Issue Paper, 15 June 2006.
} 
disabilities in a core human rights instrument. The UNCRPD, adopted by the UNGA on 13 December 2006, and entering into force in 2008, was seen to be "the culmination of two and a half decades of development in international human rights law aimed at addressing human rights violations experienced by people with disabilities". ${ }^{44}$ The UNCRPD defines "people with disabilities" as inclusive of "those who have long-term physical, mental, intellectual or sensory impairments which in interaction with various barriers may hinder their full and effective participation in society on an equal basis with others". ${ }^{55}$ of particular significance is the observation that: ${ }^{.6}$

[t]he use of the word 'include' ... allows for a non-exhaustive description of 'disability' that is not settled; neither are the meanings of terms such as 'long-term' and 'impairments'. It is accepted by the Committee on the Rights of Persons with Disabilities that people with a 'mental illness' (referred to as having a 'psychosocial disability') fall under the Convention ... 'Disability' is not formally defined in the [UNCRPD], allowing individual State Parties considerable latitude in how they define disability in their domestic law.

It has been suggested that the hesitancy to postulate precise definitions, particularly of mental illness, stems from the desire of norm-creators to accommodate an understanding of "disability", which is constantly evolving and limits the exclusion of persons whose conditions do not align with the rigid definitions. ${ }^{57}$

It is pertinent also to note that, while the UNCRPD was preceded by several international standards of good practice ${ }^{58}$ pertaining to mental health, these standards were not legally binding. In fact, these standards can now be considered to add normative content $^{59}$ to the legally binding provisions of the UNCRPD, and can be deployed as interpretative guides to treaty obligations. ${ }^{60}$ The UNCRPD, which enshrines the social model $^{61}$ of disability, shifts the view of persons with disability as "objects of charity,

\footnotetext{
${ }^{54}$ Ibid., at 46.

${ }^{55}$ Convention on the Rights of Persons with Disabilities, 13 December 2006, GA Res. 61/106, UN Doc. A/RES/61/106 (entered into force 3 May 2008) Annex I, art. 1 [CRPD].

${ }^{56}$ George SZMUKLER, Rowena DAW, and Felicity CALLARD, "Mental Health Law and the UN Convention on the Rights of Persons with Disabilities" (2014) 37(3) International Journal of Law and Psychiatry 245.

${ }^{57}$ Richard M. DUFFY and Brendan D. KELLY, "Concordance of the Indian Mental Healthcare Act 2017 with the World Health Organization's Checklist on Mental Health Legislation" (2017) 11 International Journal of Mental Health Systems 48, online: International Journal of Mental Health Systems <https://ijmhs.biomedcentral.com/ articles/10.1186/s13033-017-0155-1>, citing Vandana PETERSON, “Understanding Disability under the Convention on the Rights of Persons with Disabilities and its Impact on International Refugee and Asylum Law" (2014) 42 Georgia Journal of International and Comparative Law 687.

58 See Declaration on the Rights of Mentally Retarded Persons, 20 December 1971, GA Res. 2856 (XXVI), UN Doc. A/ RES/2856(XXVI) (1971); Principles for the Protection of Persons with Mental Illness and for the Improvement of Mental Health Care, 17 December 1991, GA Res. 46/119. UN Doc. ST/HR/1/Rev. 6 (Vol. 1/Part 1) (1991); Standard Rules on the Equalization of Opportunities for Persons with Disabilities, 20 December 1993, GA Res. 48/96, UN Doc. A/ RES/48/96 (1993); World Psychiatric Association, "Declaration of Madrid" (25 August 1996), online: University of Minnesota, Human Rights Library <http://hrlibrary.umn.edu/instree/madrid1996.html>; WHO, "Mental Health Care Law: Ten Basic Principles" (1996), online: WHO <https://apps.who.int/iris/bitstream/handle/ 10665/63624/WHO_MNH_MND_96.9.pdf?sequence=1>.

${ }^{59}$ Marks, Verdeli, and Willis, supra note 8 at 192.

${ }^{60}$ Ventura, supra note 48 at 4.

${ }^{61}$ Marianne SCHULZE, Understanding the UN Convention on the Rights of Persons with Disabilities: A Handbook on the Rights of Persons with Disabilities, 3rd ed. (New York: Handicap International, 2010), online: International Disability Alliance <https://www.internationaldisabilityalliance.org/sites/default/files/documents/hi_crpd_manual2010. pdf>; Marks, Verdeli, and Willis, supra note 8 at 199.
} 
medical treatment and social protection" 62 to "subjects of rights, able to claim those rights as active members of society" 63 by recognizing them, explicitly, as a protected class in a formal legal framework, as well as by enabling the evolution of perceptions pertaining to and the terminology employed while addressing them. ${ }^{64}$ This model is further mainstreamed by the Committee on the Rights of Persons with Disabilities, while producing authoritative guidance on the provisions of the Convention in the form of General Comments. ${ }^{65}$ The objective of the UNCRPD, in embedding such a model, is to guide domestic policy making towards an inclusive society compliant with international standards.

As per the Report on Mental Health and Human Rights (2017), the UNCRPD is key to these efforts in relation to the rights of persons with mental disabilities, as it "reflects the most advanced international human rights standards on the rights of persons with psychosocial disabilities", 66 depicting as well as demonstrating the cross-cutting nature of these rights, across the international human rights framework. This is exemplified by the provisions of the UNCRPD, as interpreted by the United Nations High Commissioner for Human Rights, which mandates non-discrimination in the fulfilment of human rights without impairing qualifiers (arts. 3 and 4$) ;{ }^{67}$ equal recognition before the law as inclusive of enjoying and exercising legal capacity on an equal basis (art. $12) ;^{68}$ the absolute ban on the deprivation of liberty on the basis of impairments and prohibition on forced treatment or harmful practices during deprivation of liberty (arts. 1417); $;^{69}$ accountability inclusive of remedial measures (art. 13) and monitoring (art. 16), as well as review and corrective actions in the context of facilities or services for persons with disabilities; ${ }^{70}$ meaningful participation of persons with psychosocial disabilities at all stages of planning and implementation (art. 4(3)) ${ }^{71}$ and technical support and capacity building in the realm of mental health (art. 32 read alongside art. 2(1) of the ICESCR). ${ }^{72}$ As shall be evidenced by the regulatory framework guaranteeing the right to mental health in India in Part III of this article, the UNCRPD has provided the impetus for the promulgation of mental healthcare legislation in most of the countries that have ratified it. ${ }^{73}$

Despite the greater clarity about the normative framework applicable to the right to mental health, progress in bringing practice in conformity with this rights-framework remains slow. ${ }^{74}$ While the interdependence of physical health and mental health, as well as the intrinsic linkages between the right to the highest attainable standard of health and other human rights, calls for States to adopt an approach according equal value to physical and mental health, such parity is not enjoyed by mental health in national policies, practices, norms, education, or budgets anywhere in the world. ${ }^{75}$ The

\footnotetext{
${ }^{62}$ OHCHR, "Statement by Louise Arbour" (5 December 2006) at 1, online: OHCHR <http://www2.ohchr.org/ english/issues/disability/docs/statementhcdec06.doc>.

${ }^{63}$ Ibid.

${ }^{64}$ Marks, Verdeli, and Willis, supra note 8 at 199.

${ }^{65}$ See "Committee on the Rights of Persons with Disabilities: General Comments", online: OHCHR <https:// www.ohchr.org/en/hrbodies/crpd/pages/gc.aspx>.

${ }^{66}$ UN Doc. A/HRC/34/32 (2017), supra note 16 at para. 22.

${ }^{67}$ Ibid., at paras. $22-4$.

${ }^{68}$ Ibid., at paras. $25-8$.

${ }^{69} \mathrm{Ibid}$., at paras. $29-33$.

${ }^{70}$ Ibid., at paras. $47-50$.

${ }^{71}$ Ibid., at para. 44.

72 Ibid., at para. 60.

${ }^{73}$ Duffy and Kelly, supra note 57.

${ }^{74}$ UN Doc. A/HRC/35/21 (2017), supra note 27 at para. 12; UN Doc. A/HRC/44/48 (2020), supra note 4; Marks, Verdeli, and Willis, supra note 8 at 200.

${ }^{75}$ UN Doc. A/HRC/34/32 (2017), supra note 16 at para. 21; UN Doc. A/HRC/35/21 (2017), supra note 27 at para. 6
} 
failure of States to equally prioritize mental health has resulted in the negation of equal protection for persons grappling with mental health concerns, the amplification of vulnerabilities among groups of persons susceptible to developing such concerns, negligence in attending to underlying determinants causative of poor mental health, marginalization of effective and appropriate treatment alternatives, stalled deinstitutionalization, and continued investment in the reductionist biomedical model ${ }^{76}$ - with repercussions for the future. These cracks are beginning to deepen more than ever in the COVID-19 pandemic, with mental health being situated at the "bottom of the list of health priorities". ${ }^{7}$ In the forthcoming segment of the article, the authors shall establish the non-derogability of the right to mental health as well as analyse the contours of its non-derogability, with the endeavour of urging the realization that States are obligated to continue ensuring that the right is respected, protected, and fulfilled even during the pandemic.

\section{Non-derogability of the Right to Mental Health}

While "there can be no health without mental health"78 has become a widely used catchphrase in the discourse surrounding mental health, the near-insignificant value and nonrights status attached to it in the law and policy framework of most countries convey a different message. Prior to the COVID-19 pandemic, statistics pertaining to mental health were already alarming, with depression affecting 264 million people in the world and the ratio of mental health professionals to persons being 1:10,000 globally. The intrinsic connection between the early onset of mental health conditions and suicide as a cause of death among young people, massive economic losses, the non-alignment of domestic laws and policies with the international rights-framework, severe human rights violations against persons grappling with poor mental health, ${ }^{79}$ and the COVID-19 pandemic all threaten to lead to an even more worrisome situation. ${ }^{80}$ Despite the grave impact of mental health conditions on individuals as well as their families and communities, mental health continues to be characterized by decision-making which impedes the realization of the right. ${ }^{81}$ Furthermore, such actions fall foul of the obligations imposed on States by the rights-framework which, even for economic, social, and cultural rights, is comprised of obligations of results alongside obligations of conduct ${ }^{82}$ in order to guarantee a "social protection baseline" 83 in the absence of which the raison d'etre of the framework

\footnotetext{
${ }^{76}$ UN Doc. A/HRC/35/21 (2017), supra note 27 at paras. 12-3.

${ }^{77}$ World Federation for Mental Health, "Appeal for National Plans for Mental Health During the Coronavirus Global Emergency” (22 April 2020), online: World Federation for Mental Health <https://wfmh.global/mentalhealth-and-covid-19-appeal/>.

${ }^{78}$ Brock CHISHOLM, "Outline for a Study Group on World Health and the Survival of the Human Race: Material Drawn from Articles and Speeches" (1951), online: WHO <https://apps.who.int/iris/bitstream/handle/10665/ 330666/MH.276.51-eng.pdf?sequence=1\&isAllowed=y>; UN Doc. A/HRC/35/21 (2017), supra note 27 at para. 6; World Federation for Mental Health, supra note 77.

${ }^{79}$ United Nations, "Policy Brief: COVID-19 and the Need for Action on Mental Health" (13 May 2020) at 5, online: United Nations Sustainable Development Group <https://www.un.org/sites/un2.un.org/files/un_policy_ brief-covid_and_mental_health_final.pdfs.

${ }^{80}$ World Federation for Mental Health, supra note 77; WHO, "World Mental Health Day: An Opportunity to Kick-Start a Massive Scale-Up in Investment in Mental Health" (27 August 2020), online: WHO <https://www. who.int/news/item/27-08-2020-world-mental-health-day-an-opportunity-to-kick-start-a-massive-scale-up-ininvestment-in-mental-health>.

${ }^{81}$ UN Doc. A/HRC/34/32 (2017), supra note 16 at para. 19; United Nations, supra note 79 at 6; Asanbe, Gaba, and Yang, supra note 7.

${ }^{82}$ UN Doc. E/1991/23 (1990), supra note 19 at para. 1.

${ }^{83}$ Diane DESIERTO, "Calibrating Human Rights and Necessity in a Global Public Health Emergency: Revive the UN OHCHR's ICESCR Compliance Criteria” (26 March 2020), online: EJIL:Talk! <https://www.ejiltalk.org/
} 
would be under question. In this segment of the article, the authors enumerate and analyse the facets of the right to mental health which are non-derogable, in pursuance of which the need to urge and monitor States' realization of the right as continuous arises, ${ }^{84}$ regardless of the prevailing COVID-19 pandemic.

\section{A. States' Core Obligation to Fulfil Minimum Essential Levels of the Right to Mental Health}

While economic, social, and cultural rights guaranteed by the international rights-framework are subject to "the maximum of [a State Party's] available resources" 85 and progressive realization, ${ }^{86}$ the CESCR has recognized that States Parties have a core obligation to fulfil the minimum essential levels of each right ${ }^{87}$ which are obligations of results. ${ }^{88}$ As per the CESCR, in the absence of a requirement to fulfil such minimum obligations, the raison d'etre of the Covenant would be under question. ${ }^{89}$ The core obligation to fulfil minimum essential levels of a right extends to the right to the highest attainable standard of health, ${ }^{90}$ and as much to mental health as to physical health. ${ }^{91}$ These minimum core obligations attached to the right to the highest attainable standard of physical and mental health have been explicitly recognized by the CESCR as nonderogable. $^{92}$ In respect of mental health, States have thus been called upon to ensure availability, accessibility, and affordability of mental health facilities, goods, and services on a non-discriminatory basis, respect for autonomy and agency of persons with mental disabilities, meaningful participation of stakeholders including through effective community action, and accountability and effective remedial measures. ${ }^{93}$ Moreover, as per the CESCR, while "measures to prevent, treat and control epidemic and endemic diseases" 94 are obligations which are comparable in priority to the States' core obligations, "it should be stressed, however, that a State party cannot, under any circumstances whatsoever, justify its non-compliance with the core obligations ... which are non-derogable." 95 States thus have no grounds to claim that the right to mental health is not a core obligation with minimum essential levels to be fulfilled, nor can they justify any persistent and continued non-compliance with these minimums by asserting any number of reasons including the COVID-19 pandemic.

Furthermore, while the resources of the State as well as its economic condition must be considered while reviewing whether a State has discharged its core obligation with respect to the minimums, the parameters of the review include assessing whether the State has employed the resources at its disposition optimally with the objective of full realization of the minimums as well as whether it has devised comprehensive strategies

calibrating-human-rights-and-necessity-in-a-global-public-health-emergency-revive-the-un-ohchrs-icescr-compliance-criteria/>.

${ }^{84}$ Ibid.

${ }^{85}$ ICESCR, art. 2(1); CRPD, art. 4(2).

${ }^{86}$ Ibid.

${ }^{87}$ UN Doc. A/HRC/34/32 (2017), supra note 16 at para. 8; UN Doc. E/1991/23 (1990), supra note 19 at para. 10.

${ }^{88}$ UN Doc. A/HRC/35/21 (2017), supra note 27 at para. 37.

${ }^{89}$ UN Doc. E/1991/23 (1990), supra note 19 at para. 10.

${ }^{90}$ Ibid.

${ }^{91}$ UN Doc. A/HRC/34/32 (2017), supra note 16 at para. 8.

92 UN Doc. E/C.12/2000/4 (2000), supra note 12 at para. 47; Desierto, supra note 83.

${ }^{93}$ UN Doc. A/HRC/34/32 (2017), supra note 16 at para. 9.

${ }^{94}$ UN Doc. E/C.12/2000/4 (2000), supra note 12 at para. 44(c).

${ }^{95}$ Ibid., at para. 47; Amnesty International, "Responses to COVID-19 and States' Human Rights Obligations: Preliminary Observations” (16 March 2020), online: Amnesty International <https://www.amnestyusa.org/ press-releases/responses-to-covid-19-and-states-human-rights-obligations-preliminary-observations/>. 
and programs for it. ${ }^{96}$ Despite the absence of a bifurcation or hierarchy between physical and mental health within the rights-framework, however, in most countries, an arbitrary division is made between physical health and mental health with the former being prioritized. ${ }^{97}$ Resultantly, the resources allocated to mental health facilities, goods, and services as well as for an assessment of the impact of policy measures pertaining to mental health are fewer than those allocated to physical health, and the minimal investment being made in mental health centres around the biomedical model. ${ }^{98}$ Thus, despite the recognition of the non-derogability of the core obligations on States in respect of mental health, neither are resources allocated to it at parity with physical health nor are the scant resources allocated utilized in an optimal manner for the realization of the minimum essential levels of the right. To address these contraventions, States should accord priority to a human rights-based approach to mental health informed by the international rights-framework, as well as adopt a "do no harm" criteria for the evaluation of their efforts. ${ }^{99}$

\section{B. The Illimitable Character of the 'Freedoms' Component of the Right to Mental Health}

The right to health is constituted of freedoms and entitlements, the former being inclusive of control over one's own health, as well as freedom from coercion in medical treatment, and the latter referencing the right to a non-discriminatory system of health protection. ${ }^{100}$ While the right to the highest attainable standard of health is subject to resource constraints and progressive realization, much like core obligations, the "freedoms" component of the right to health is not limited by these constraints. ${ }^{101}$ In pursuance, it has been recognized by the Special Rapporteur that: ${ }^{102}$

[t]he evolving normative context around mental health involves the intimate connection between the right to health, with the entitlement to underlying determinants, and the freedom to control one's own health and body. That is also linked to the right to liberty, freedom from non-consensual interference and respect for legal capacity. While informed consent is needed to receive treatment that is compliant with the right to health, legal capacity is needed to provide consent and must be distinguished from mental capacity ... The denial of legal capacity frequently leads to deprivation of liberty and forced medical interventions, which raises questions not only about the prohibition of arbitrary detention and cruel, inhuman or degrading treatment, but also the right to health.

Despite such formal recognition however, several national legal frameworks continue to deny persons with mental health conditions the right to make their own decisions and/or access information required to freely exercise consent. ${ }^{103}$ These practices are often also accompanied by the use of coercion, justified on the basis of "medical necessity" and the "danger" of the person with the condition. ${ }^{104}$ Not only do such practices contravene

\footnotetext{
${ }^{96}$ UN Doc. E/1991/23 (1990), supra note 19 at paras. 10-1.

${ }^{97}$ UN Doc. A/HRC/34/32 (2017), supra note 16 at para. 21; UN Doc. A/HRC/35/21 (2017), supra note 27 at para. 6.

${ }^{98}$ Ibid., Asanbe, Gaba, and Yang, supra note 7.

${ }^{99}$ UN Doc. A/HRC/34/32 (2017), supra note 16 at paras. 45-6.

${ }^{100}$ UN Doc. A/HRC/34/32 (2017), supra note 16 at para. 7; Asanbe, Gaba, and Yang, supra note 7.

${ }^{101}$ UN Doc. E/1991/23 (1990), supra note 19 at para. 8; UN Doc. A/HRC/34/32 (2017), supra note 16 at para. 7; UN Doc. A/HRC/35/21 (2017), supra note 27 at para. 37.

${ }^{102}$ UN Doc. A/HRC/35/21 (2017), supra note 27 at para. 31. See also paras. 25, 33.

103 Ibid., at paras. $25-8$.

${ }^{104}$ UN Doc. A/HRC/35/21 (2017), supra note 27 at para. 64.
} 
States' obligations, they also further embed stigma against persons with mental disabilities, erode trust, and perpetuate power asymmetries, with the cumulative effect being aversion to and fear of the mental health services. ${ }^{105}$ Given that the "freedoms" component of the right to mental health cannot be subjected to limitations, States should repeal contravening legal provisions and implement non-coercive alternatives, accord priority to the will of the individual, and even where such determination is difficult, mainstream "the best interpretation of will and preferences of the individual". ${ }^{106}$

\section{The Duty to Take Steps through International Assistance and Cooperation}

The right to the highest attainable standard of health, much like other economic, social, and cultural rights guaranteed by the international rights-framework, is to be realized through targeted, deliberate, and concrete steps ${ }^{107}$ taken by a State individually, as well as through international assistance and cooperation. ${ }^{108}$ The maximum resources available to a State are thus inclusive of resources available to it from within the State as well as outside of it, ${ }^{109}$ and its duty to take steps towards the progressive realization of the right to mental health includes steps taken through international assistance and cooperation. ${ }^{110}$ In the context of mental health, international assistance, when available, has been used primarily to upgrade or renovate large psychiatric institutions or hospitals, which has resulted in efforts towards deinstitutionalization being undermined. ${ }^{111}$ Investment in, and advancement of such measures which impede progress, not only defeat the purpose of seeking international assistance and cooperation, but also likely contravene the prohibition on unjustifiable retrogressive measures. ${ }^{112}$ Furthermore, given the frequent occurrences of human rights violations in such institutions, States are bound by an obligation of results to "refrain from providing development cooperation supporting mental healthcare systems that are discriminatory or where violence, torture and other human rights violations occur". ${ }^{113}$ The need of the hour is cooperation over rights-based development in mental healthcare, which is focused on delivery in the community, ${ }^{114}$ and which adheres to the principles enshrined within global standards and as culled out by supranational norm-creators.

\section{The Impermissibility of Unjustifiable Non-Retrogressive Measures}

A strong presumption of impermissibility is attached to retrogressive measures taken in relation to economic, social, and cultural rights, including to the right to health. ${ }^{115}$ Any deliberately retrogressive measures taken will require the State to discharge the burden

\footnotetext{
${ }^{105}$ Ibid., at para. 65 .

${ }^{106}$ UN Doc. A/HRC/34/32 (2017), supra note 16 at paras. 26, 28; UN Doc. A/HRC/35/21 (2017), supra note 27 at para. 66.

${ }^{107}$ UN Doc. E/1991/23 (1990), supra note 19 at para. 2.

${ }^{108}$ ICESCR, art. 2 (1); CRPD, arts. 4(2), 32; Transforming Our World, supra note 25 at Goal 17.

${ }^{109}$ UN Doc. E/1991/23 (1990), supra note 19 at para. 13.

${ }^{110}$ UN Doc. A/HRC/34/32 (2017), supra note 16 at para. 60.

${ }^{111}$ UN Doc. A/HRC/35/21 (2017), supra note 27 at paras. 12, 39.

112 UN Doc. E/C.12/2000/4 (2000), supra note 12 at paras. 32, 48; UN Doc. E/1991/23 (1990), supra note 19 at para. 9.

${ }^{113}$ UN Doc. A/HRC/35/21 (2017), supra note 27 at para. 38 .

${ }^{114}$ Ibid. Rights of Persons with Disabilities, Report of the Special Rapporteur on the Rights of Persons with Disabilities, UN Doc. A/HRC/46/27 (2021), at para. 92.

${ }^{115}$ UN Doc. E/C.12/2000/4 (2000), supra note 12 at para. 32
} 
of proving that the introduction of the measures is justified on the basis of a careful consideration of all available alternatives, as well as by reference to the totality of the rights provided for in the Covenant, subject to the State's maximum available resources. ${ }^{116}$ Further, retrogressive measures incompatible with the core obligations of a right constitute a violation. ${ }^{117}$ Thus, non-retrogression can be understood to be one of the cross-cutting obligations constituting the "social protection baseline"118 in the ICESCR, alongside core minimums and non-discrimination which, in the absence of a derogation clause, cannot be subject to derogations by States. Moreover, even in situations of severe resource constraints, not only is the impermissibility on unjustifiable nonretrogression not qualified, States are actually obligated to pro-actively protect vulnerable members of the society through targeted cost-effective programs. ${ }^{119}$ Therefore, States' progress towards the realization of the right to mental health in a non-discriminatory manner and on a non-retrogressive basis must be monitored continuously, regardless of the existence or nature of an ongoing crisis.

\section{E. The Key Interlinkages between the Right to Mental Health and other Human Rights}

The right to mental health as a human right is one of the components of the right to an adequate standard of living for the health and well-being of individual. ${ }^{120}$ By virtue of this, there are key interlinkages between the right to mental health and other human rights, ${ }^{121}$ inclusive of but not limited to the rights to housing, work, education, food and water, equality, non-discrimination, life, liberty, human dignity, prohibition against torture, privacy, and access to justice. Furthermore, the UNCRPD specifically codifies several rights guaranteed by the International Bill of Rights, alongside the right to health, articulated in the UNCRPD in a manner so as to have particular relevance for persons with disabilities, ${ }^{122}$ including persons with mental disabilities. The strong interlinkages between the right to mental health and other human rights operate in such a manner that any advancement in the realization of either one synergistically implicates the other. However, by extension, violations of or regression in the realization of either one also detrimentally impacts the other.

While the COVID-19 pandemic "vividly illustrates the importance of the indivisibility and interdependence of all human rights", ${ }^{123}$ it also demonstrates the prolonged neglect meted out to the issue of mental health. The low priority accorded to economic, social, and cultural rights, ${ }^{124}$ and in particular to mental health due to the visible implications of the pandemic for physical health, render Bennoune's reminder of great significance

\footnotetext{
${ }^{116}$ Ibid., UN Doc. E/1991/23 (1990), supra note 19 at para. 9.

${ }^{117}$ UN Doc. E/C.12/2000/4 (2000), supra note 12 at para. 48.

${ }^{118}$ Desierto, supra note 83.

${ }^{119}$ UN Doc. E/1991/23 (1990), supra note 19 at para. 12.

${ }^{120}$ UDHR, art. 25; Marks, Verdeli, and Willis, supra note 8 at 184.

${ }^{121}$ See UN Doc. A/HRC/34/32 (2017), supra note 16 at paras. 7, 13, 29, 31, 59; UN Doc. A/HRC/RES/36/13 (2017), supra note 20; Human Rights Watch, supra note 14; Marks, Verdeli, and Willis, supra note 8 at 184-5.

${ }^{122}$ Cameron, supra note 50.

${ }^{123}$ Committee on Economic, Social and Cultural Rights, Statement on the Coronavirus Disease (COVID-19) Pandemic and Economic, Social and Cultural Rights, 6 April 2020, UN Doc. E/C.12/2020/1 (2020), at para. 3, online: United Nations Economic and Social Council <https://documents-dds-ny.un.org/doc/UNDOC/GEN/G20/095/28/PDF/ G2009528.pdf?OpenElement>.

${ }^{124}$ Report of the Special Rapporteur on the Right of Everyone to the Enjoyment of the Highest Attainable Standard of Physical and Mental Health, Dainius Pūras, UN Doc. A/HRC/29/33 (2015), at para. 53; see also UN Doc. A/HRC/ 34/32 (2017), supra note 16 at para. 14.
} 
at this juncture. In the context of COVID-19, and human rights more generally, she notes: ${ }^{125}$

In constructing holistic human rights responses going forward, we must remember that what is particular about the COVID-19 pandemic is the totality of the potential threat to most human rights around the world in a relatively compressed timeframe .... A pandemic requires nothing less than a pan-normative approach. This means actually taking into consideration the range of rights: civil, cultural, economic, political, and social .... Indeed, the connections between all categories of rights are critical to consider in this crisis. COVID-19 reminds us that the bifurcation of the covenants on civil and political rights and on economic, social, and cultural rights, was a political and legal choice, not a reflection of the lived reality of the exercise of rights.

Therefore, a legal and policy environment which displays cognizance for the interdependencies between mental health and the vast array of human rights, which emphasizes on the centrality of a human rights-based approach to mental health, amidst and in the aftermath of the pandemic.

The low prioritization accorded to mental health by almost all countries, ${ }^{126}$ the continued dominance of the biomedical model as opposed to the human rights-based approach to mental health, ${ }^{127}$ and the "tendency to undermine the importance of economic, social and cultural rights" 128 have, cumulatively, yielded grave implications for the right to an adequate standard of living for persons grappling with mental health concerns. They have also led to the perpetuation of inequality and the disempowerment of large sections of States' populations, as well as the continued threat of widespread human rights violations. With the onset and prolonged persistence of the COVID-19 pandemic, the years of neglect and reluctance to take measures to progressively realize mental health as a human right have led to the revelation and amplification of the shortcomings in guaranteeing the right at the domestic level. In the forthcoming part, the authors illustrate this argument by training a lens on India's efforts to guarantee the right to mental health. In particular, the focus of this part shall be on the implications of India's response to the pandemic for the right to mental health, and on proposing recommendations that can potentially bridge the chasm between the international and domestic regulatory frameworks.

\section{India's Response to the Pandemic and Its Implications for the Right to Mental Health}

Since ancient times, it has been recognized that mental health is an intrinsically important component of the lived reality of every individual, and that the integrity of the human mind is as inviolable as that of the human body's. ${ }^{129}$ However, for far too long, persons impaired by poor mental health have been treated as objects of charity rather than as subjects in relation to the law. ${ }^{130}$ Moreover, while the Indian legislative framework

\footnotetext{
${ }^{125}$ Karima BENNOUNE, “Lest We Should Sleep": COVID-19 and Human Rights" (2020) 114 American Journal of International Law 666.

${ }^{126}$ UN Doc. A/HRC/35/21 (2017), supra note 27 at paras. 6-8; World Federation for Mental Health, supra note 77.

${ }^{127}$ UN Doc. A/HRC/35/21 (2017), supra note 27 at paras. 18-9.

${ }^{128}$ UN Doc. A/HRC/29/33 (2015), supra note 124 at para. 53; UN Doc. A/HRC/34/32 (2017), supra note 16 at para. 14.

${ }^{129}$ D. NAGARAJA and Pratima MURTHY, eds., Mental Health Care and Human Rights (New Delhi: National Human Rights Commission, 2008) at 7, 16.

${ }^{130}$ Ibid., at 7.
} 
guaranteeing the right to mental health is seemingly extensive, the shift to a rights-based approach has been slow, its implementation has been ineffective, and it has scarcely been accompanied by periodical monitoring and measures aimed at sensitization. ${ }^{131}$ These insufficiencies, which are telling about the priority accorded to understand and ensure the mental health needs of individuals in India, have heightened during the pandemic.

In this part of the article, the authors shall outline the legislative and policy framework governing the right to mental health, attempting to showcase its shortcomings. By drawing on the conditions of healthcare/frontline workers and migrant workers as case-studies, the authors shall illustrate how concerns pertaining to mental health have amplified during the pandemic, particularly for the vulnerable and marginalized sections of the Indian society. In doing so, the authors attempt to highlight the need for policy makers to realize, now more than ever, that creating an enabling environment, which nurtures and promotes mental health and well-being as a human right for all, with a focus on the more vulnerable, is of great importance. This segment shall also discuss the more successful efforts of the government to mitigate the harm to individuals' mental health and well-being as well as detail a few recommendations in order to provide a glimpse into the possible way forward.

\section{A. The Legislative and Policy Framework Governing the Right to Mental Health in India}

Marred by a colonial past, India's legislative and policy framework was significantly influenced by the British. India's law reflected the outcomes of the hybridity between the colonizer and the colonized in the "Postcolony". ${ }^{132}$ The Indian Lunacy Act 1912, ${ }^{133}$ and $1977,{ }^{134}$ which was the first legislation to govern "mental health" in India, was illustrative of this. The legislation pertained to the identification, detention, and treatment of "lunatics" in asylums. ${ }^{135}$ Consequently, India's inheritance of the Act entailed the problematic dimensions of the English counterpart, which included, but was not limited to, the protection of the general public from people who were considered a danger to society - in complete disregard of present-day human rights norms. ${ }^{136}$

Realizing the pitfalls of this particular legislation, the National Mental Health Programme was launched in $1982,{ }^{137}$ which paved the way to a major overhaul and the enactment of the Mental Health Act 1987. ${ }^{138}$ Enacted with the "objective of consolidating the law relating to the treatment and care of mentally ill persons and to make better provisions with respect to their property and affairs", ${ }^{139}$ the Act seemed to mark a step in the right

\footnotetext{
${ }^{131}$ Suresh Bada MATH and D. NAGARAJA, "Mental Health Legislation: An Indian Perspective” in D. NAGARAJA and Pratima MURTHY, eds., Mental Health Care and Human Rights (New Delhi: National Human Rights Commission, 2008), 49 at 67.

${ }^{132}$ Eve DARIAN-SMITH, "Postcolonial Theories of Law" in Reza BANAKAR and Max TRAVERS, eds., Law and Social Theory, 2nd ed. (Oxford: Hart Publishing, 2013), 247.

133 Indian Lunacy Act, 1912, Act No IV of 1912, online: India Code <https://www.indiacode.nic.in/bitstream/ 123456789/11080/1/indian_lunacy_act_1912.pdf>.

${ }^{134}$ Indian Lunacy Act, 1977. Kaushik LAIK, "Saga of the 'Mental Revolution' in India: A Critical Overview of the Indian Mental Health Laws in Light of the International and Domestic Societal Scenarios" (2005) 31 Commonwealth Law Bulletin 41.

${ }^{135}$ Indian Lunacy Act, 1912, at Part II, supra note 133.

${ }^{136}$ Muhammad Mudasir FIRDOSI and Zulkarnain Z. AHMAD, "Mental Health Law in India: Origins and Proposed Reforms” (2016) 13(3) British Journal of Psychiatry International 65.

${ }^{137}$ Ministry of Health and Family Welfare, Government of India, "National Mental Health Programme", online: Ministry of Health and Family Welfare <https://main.mohfw.gov.in/sites/default/files/9903463892NMHP\% 20detail_0_2.pdf>.

${ }^{138}$ Nagaraja and Murthy, supra note 129.

139 The Mental Health Act, 1987, at Preamble, online: Government of West Bengal <https://www.wbhealth.gov. in/mental_health/Acts_Rules/MHA_1987.pdf> [Mental Health Act, 1987].
} 
direction. However, since its enactment, it has been the target of criticism, ${ }^{140}$ especially at the hands of human rights activists. ${ }^{141}$ The primary criticism levelled against it has been its failure to adequately recognize and protect the agency of persons with mental illnesses. ${ }^{142}$ It has also been criticized for lacking a comprehensive definition of mental illness, ${ }^{143}$ a term which is defined by the Act solely for the purposes of the admission into and treatment of persons in mental hospitals. ${ }^{144}$ The Act was treatment-specific, prescribed a procedure for involuntarily admission and treatment, ${ }^{145}$ and lacked a coherent appeal and review process accessible to patients with mental illnesses in such custodial care institutions. ${ }^{146}$ Essentially, the Act sought to regulate the admission and treatment of persons with severe mental illness when they were detained against their will ${ }^{147}$ in mental hospitals. ${ }^{148}$ Human rights activists have challenged the validity of the Act under Articles $14^{149}$ and $21^{150}$ of the Indian Constitution, contending that it results in the indefinite and wrongful curtailment of personal liberty, since it is not subject to proper judicial review. ${ }^{151}$ Beyond the incongruence of the Act with the promise of human rights, the Act was impenetrable due to complex procedures, ${ }^{152}$ and was inadequately supplemented by investments in the development of mental health infrastructure in the country. ${ }^{153}$

The surge in the international movement towards the recognition of the right to mental health in the post-1990s era, alongside the deficiencies in the implementation of the Mental Health Act 1987, rendered the Act increasingly obsolete. Concomitantly, the movement opened up the space for new legislative and policy initiatives which aligned with the principles and ethos of the global developments. Notably, a pivotal point was marked by the UNGA Resolution on the Principles for the Protection of the Persons with Mental Illness and for the Improvement of Mental Health Care (1991), which recognized the fundamental freedoms and basic freedoms ${ }^{154}$ of persons with mental illnesses. These included being treated with humanity, and the guarantee of respect for the inherent dignity of the

\footnotetext{
${ }^{140}$ Pratima MURTHY, B.C. MALATHESH, C. Naveen KUMAR, and Suresh Bada MATH, "Mental Health and the Law: An Overview and Need to Develop and Strengthen the Discipline of Forensic Psychiatry in India" (2016) 58 Indian Journal of Psychiatry S181; Choudhary Laxmi NARAYAN and Deep SHIKHA, "Indian Legal System and Mental Health" (2013) 55 Indian Journal of Psychiatry S177.

${ }^{141}$ Choudhary Laxmi NARAYAN, M. NARAYAN, and Deep SHIKHA, "The Ongoing Process of Amendments in MHA-87 and PWD Act-95 and their Implications on Mental Health Care" (2011) 53 Indian Journal of Psychiatry 343; Narayan and Shikha, supra note 140.

${ }^{142}$ Narayan, Narayan, and Shikha, supra note 141

${ }^{143}$ Suresh Bada MATH, Vinay BASAVARAJU, Shashidhara Magabhushana HARIHARA, Guru S. GOWDA, Narayana MANJUNATHA, Channaveerachari Naveen KUMAR, and Mahesh GOWDA, "Mental Healthcare Act 2017-Aspiration to Action" (2019) 61 Indian Journal of Psychiatry S660.

${ }^{144}$ Mental Health Act, 1987, section 2(l).

${ }^{145}$ Mental Health Act, 1987, Part II, Chapter IV.

${ }^{146}$ Suresh Bada MATH, Pratima MURTHY, and Channapatna R. CHANDRASHEKAR, "Mental Health Act (1987):

Need for a Paradigm Shift from Custodial to Community Care" (2011) 133 Indian Journal of Medical Research 246.

${ }^{147}$ Math, Basavaraju, Harihara, Gowda, Manjunatha, Kumar, and Gowda, supra note 143.

${ }^{148}$ Ibid.

${ }^{149}$ Constitution of India, 1950, Article 14 - Right to Equality.

${ }^{150}$ Constitution of India, 1950, Article 21 - Right to Life.

${ }^{151}$ Narayan, Narayan, and Shikha, supra note 141 citing Amita DHANDA, "Status Paper on Rights of Persons Living with Mental Illness in the Light of the UNCRPD" in Amita DHANDA and Rajiv RATURI, eds., Harmonizing Laws with the UNCRPD (New Delhi: Human Rights Law Network, 2010), 201.

${ }^{152}$ Narayan, Narayan, and Shikha, supra note 141; Narayan and Shikha, supra note 140.

${ }^{153}$ Math, Murthy, and Chandrashekar, supra note 146.

${ }^{154}$ Principles for the Protection of Persons with Mental Illness and for the Improvement of Mental Health Care, supra note 58, Principle 1.
} 
human person. ${ }^{155}$ Another development which created the impetus for India to overhaul its mental health legislative and policy framework was the UNCRPD, ${ }^{156}$ which India ratified in $2007 .{ }^{157}$ Read alongside the non-derogable dimensions of the rights detailed in the ICESCR, another instrument which has been ratified by India, ${ }^{158}$ India's obligation to guarantee the right to mental health and well-being became increasingly robust. It also necessitated that the guarantee be framed as per the terms on which the international developments have been framed - legal capacity, equality, dignity, and recognition of human rights. ${ }^{159}$

In an attempt to harmonize domestic and international frameworks, and to adhere to its international obligations, the Indian government sought to enact new laws which promoted the principles espoused by global norms. With a rights-based approach, the need of the hour is to focus on the rights to treatment, social care, social inclusion, political empowerment, liberty, and a community-centric approach towards the implementation of the mental health laws in India. ${ }^{160}$ The international movement, alongside the gradual change in the outlook of the Indian judiciary towards the promotion of the rights of the mentally ill, ${ }^{161}$ has gradually urged improvements. Decades after its ratification of the international legal instruments, which impose obligations upon India to guarantee the right to mental health, and after many deliberations and several attempts, the Mental Healthcare Act $2017^{162}$ was enacted. It is considered to be progressive, patientcentric legislation, which is stated as having a rights-based approach as opposed to a biomedical one. The preamble of the Act seeks to provide "for mental healthcare and services for persons with mental illness and to protect, promote and fulfil the rights of such persons during delivery of mental healthcare", ${ }^{163}$ thereby seeking to adhere to the "respect-protect-fulfil" framework of human rights.

However, the Mental Healthcare Act 2017, is not without shortcomings. Apart from issues that plague other low and middle-income countries pertaining to healthcare, and more specifically to mental health - that of lack of resources, ${ }^{164}$ political will, and implementation $^{165}$ - it also fails to provide a holistic approach towards the rights of persons with mental illnesses. It focuses on treatment in hospitals and other institutions rather than providing a community-based approach. ${ }^{166}$ It fails to guarantee rights between

\footnotetext{
${ }^{155}$ Ibid., Principle 1(1).

${ }^{156}$ CRPD.

${ }^{157}$ India ratified the CRPD on 1 October 2007: Press Information Bureau, "Secretary, DePWD Participated In 22nd Session of UN Committee on CRPD at Geneva" (9 September 2019), online: Press Information Bureau <https://pib.gov.in/Pressreleaseshare.aspx?PRID=1584572>.

${ }^{158}$ India ratified the ICESCR on 10 April 1979: "Ratification Status for India", online: United Nations Human Rights Treaty Bodies <https://tbinternet.ohchr.org/_layouts/15/TreatyBodyExternal/Treaty.aspx?CountryID= 79\&Lang=EN>.

159 Narayan and Shikha, supra note 140.

${ }^{160}$ Brendan D. KELLY, Mental Illness, Human Rights and the Law (Cambridge: Cambridge University Press, 2016); Brendan D. KELLY, "Mental Health, Mental Illness, and Human Rights in India and Elsewhere: What are We Aiming For?” (2016) 58 Indian Journal of Psychiatry S168.

${ }^{161}$ Laik, supra note 134 at 46, citing the shifts in attitude from Joshi Ram Krishnan $v$ Rukmini Bai [1949] All 449 AIR and G Bhavananamma $v$ Somaraju [1957] AP 938 AIR to Sheela Barse $v$ Union of India [1987] SC 50 SCC 3.

${ }^{162}$ The Mental Healthcare Act, 2017, online: Government of India <https://legislative.gov.in/sites/default/ files/A2017-10.pdf>.

${ }^{163}$ Ibid. Preamble.

${ }^{164}$ WHO, "World Mental Health Day", supra note 80.

${ }^{165}$ Math, Basavaraju, Harihara, Gowda, Manjunatha, Kumar, and Gowda, supra note 143; Richard M. DUFFY and Brendan D. KELLY, “The Right to Mental Healthcare: India Moves Forward” (2019) 214(2) The British Journal of Psychiatry 59.

${ }^{166}$ Math, Basavaraju, Harihara, Gowda, Manjunatha, Kumar, and Gowda, supra note 143.
} 
episodes of care when there is a higher risk of violation of such rights through neglect, homelessness, imprisonment, and social exclusion. ${ }^{167}$ While defining "mental illness", 168 the Act does not account for all persons with mental illnesses. By defining "mental illness" as: ${ }^{169}$

a substantial disorder of thinking, mood, perception, orientation, or memory that grossly impairs judgment, behavior, capacity to recognize reality or ability to meet the ordinary demands of life, mental conditions associated with the abuse of alcohol and drugs, but does not include mental retardation which is a condition of arrested or incomplete development of mind of a person, especially characterized by subnormality of intelligence ... the Act accounts solely for persons with severe mental disorders who require medical/institutional intervention. ${ }^{170}$ It has been argued that neither does the Act showcase cognizance of the realities of resources and requirements contextually specific to India, ${ }^{171}$ nor does it sufficiently encourage a "whole person" approach for motivated implementation of the rights-based approach at the centralized levels, thereby necessitating amendments in order for it to be effective.

Moreover, while the Mental Healthcare Act 2017, emphasizes community-based approaches, marks a movement towards deinstitutionalization, and mandates the appropriate government to "provide for or support the establishment of less restrictive community based establishments including half-way homes, group homes, and the like for persons who no longer require treatment in more restrictive mental health establishments such as long stay mental hospitals", ${ }^{172}$ such facilities have not been established, nor has the supportive infrastructure been invested in. ${ }^{173}$ Similarly, the constitution of nodal, quasi-judicial bodies termed "Mental Health Review Boards", with a range of functions including powers to adjudicate deficiencies in care and services, inspect establishments, and impose penalties for contravention of orders pursuant to Section 73 of the Act, have not been established by several States; neither have State Mental Healthcare Authorities been constituted by several of them, as required under Section 45 of the Act. ${ }^{174}$ As of 2020 , three years from the date of the initial direction, States had only outlined a roadmap towards the implementation of the Act. ${ }^{175}$ With the onset of the COVID-19 pandemic, as of July 2021, the Supreme Court of India has remarked that: ${ }^{176}$

\footnotetext{
${ }^{167}$ Duffy and Kelly, supra note 165.

${ }^{168}$ Mental Healthcare Act, 2017, Section 2(s).

169 Ibid.

${ }^{170}$ Math, Basavaraju, Harihara, Gowda, Manjunatha, Kumar, and Gowda, supra note 143.

${ }^{171}$ Ibid.

172 Mental Healthcare Act, 2017, Section 19(3).

173 Riddhi DASTIDAR, "In India, Coronavirus Crises has been Particularly Hard for Mental Health Patients and Hospitals" IndiaSpend (3 November 2020), online: Scroll.in <https://scroll.in/article/977451/in-india-coronaviruscrisis-has-been-particularly-hard-for-mental-health-patients-and-hospitals>.

${ }^{174}$ Mental Healthcare Act, 2017, supra note 162, sections 45 and 73; Ritika GOYAL, “Three Years On, India's Progressive Mental Healthcare Act is Dogged by Gaps in Implementation" Scroll.in (10 October 2020), online: Scroll.in <https://scroll.in/article/975401/three-years-on-indias-progressive-mental-healthcare-act-is-doggedby-gaps-in-implementation>.

${ }^{175}$ Gaurav Kumar Bansal v Mr Dinesh Kumar, Supreme Court of India, order dated 10 February 2020, CONMT. PET. (C) No. $1653 / 2018$ in W.P.(C) No. $412 / 2016$

${ }^{176}$ Gaurav Kumar Bansal v Mr Dinesh Kumar, Supreme Court of India, order dated 6 July 2021, CONMT. PET. (C) No. $1653 / 2018$ in W.P.(C) No. 412/2016.
} 
... as a result of the outbreak of the Covid-19 pandemic, no progress could effectively be made ....We are of the view that the progress in implementing the judgment of this Court and the Mental Healthcare Act 2017 has been tardy and it is time that the matter is taken up with utmost alacrity by the Union Government.

The endeavour to channel global norms into the domestic framework is also evidenced by the Rights of Persons with Disabilities Act 2016, ${ }^{177}$ which replaced the Persons with Disability Act 1995. The Act of 2016, read alongside the Rights of Persons with Disabilities Rules, 2017, ${ }^{178}$ is applicable to persons with "long term physical, mental, intellectual or sensory impairment which, in interaction with barriers, hinders his full and effective participation in society equally with others." ${ }^{179}$ Much like the Mental Healthcare Act 2017, the Act emphasizes the rights of individuals with mental illnesses, including but not limited to: the rights to dignity, non-discrimination, inclusion and participation in society, individual autonomy, and accessibility - and in this sense it complements the 2017 Act. ${ }^{180}$ It also, much like the 2017 Act, marks a shift from a charity-model to a rights-based model, as well as from a medical model to a biopsychosocial model. ${ }^{181}$ However, apart from difficulties in implementation, the Rights of Persons with Disabilities Act 2016, specifically poses the following problems in the context of concerns about mental health: the suitability of its general provisions in addressing the particularities of the challenges faced by persons with mental illnesses; impediments to caregiving by families; the notions of (in) capacity inherent in the formulation of certain provisions as opposed to an emphasis on social welfare; and, pivotally, the lack of effective synchronization between the Acts of 2016 and $2017 .^{182}$

\section{B. Impact of India's Response to the COVID-I 9 Pandemic on the Right to Mental Health}

Against this backdrop, the COVID-19 pandemic has proven to be a tinderbox in the Indian context. Apart from the impact the virus has had on physical health, it has also been found to have short- as well as long-term psychological impacts. ${ }^{183}$ Such psychological impacts have been evidenced as being compounded further by the ripple effects of quarantine and nationwide lockdowns, which can induce panic, anxiety, obsessive behaviours, paranoia, and depression, and can also lead to post-traumatic stress disorder (PTSD). ${ }^{184}$ In

\footnotetext{
${ }^{177}$ The Right of Persons with Disabilities Act, 2016, online: Government of India <https://legislative.gov.in/ sites/default/files/A2016-49_1.pdf> [RPDA 2016].

178 The Right of Persons with Disabilities Act, Rules 2017, online: Government of India, <https://www.egazette. nic.in/WriteReadData/2017/174740.pdf>.

${ }^{179}$ RPDA 2016, Section 2(s).

${ }^{180}$ Duffy and Kelly, supra note 57.

${ }^{181}$ Abhilash BALAKRISHNAN, Karishma KULKARNI, Sydney MOIRANGTHEM, Channaveerachari Naveen KUMAR, Suresh Bada MATH, and Pratima MURTHY, “The Rights of Persons with Disabilities Act 2016: Mental Health Implications" (2019) 41(2) Indian Journal of Psychological Medicine 119.

${ }^{182}$ Suresh Bada MATH, Guru S. GOWDA, Vinay BASAVARAJU, Narayana MANJUNATHA, Channaveerachari Naveen KUMAR, Sharad PHILIP, and Mahesh GOWDA, "The Rights of Persons with Disability Act, 2016: Challenges and Opportunities" (2019) 61 Indian Journal of Psychiatry S809; Duffy and Kelly, supra note 57; Balakrishnan, Kulkarni, Moirangthem, Kumar, Math, and Murthy, supra note 181; Choudhary Laxmi NARAYAN and Thomas JOHN, "The Rights of Persons with Disabilities Act, 2016: Does it Address the Needs of the Persons with Mental Illness and their Families" (2017) 59 Indian Journal of Psychiatry 17.

183 Shweta SINGH, Deblina ROY, Krittika SINHA, Sheeba PARVEEN, Ginni SHARMA, and Gunjan JOSHI, "Impact of COVID-19 and Lockdown on Mental Health of Children and Adolescents: A Narrative Review with Recommendations" (2020) 293 Psychiatry Research 113429; Souvik DUBEY, Payel BISWAS, Ritwik GHOSH, Subhankar CHATTERJEE, Mahua Jana DUBEY, Subham CHATTERJEE, Durjoy LAHIRI, and Carl J. LAVIE, "Psychosocial Impact on COVID-19" (2020) 14 Diabetes \& Metabolic Syndrome: Clinical Research \& Reviews 779. 184 Ibid.
} 
India, the first nationwide lockdown was announced for an initial period of 21 days in March 2020, ${ }^{185}$ which was extended to a period of almost two months, with an ease of restrictions only after June $2020{ }^{186}$ Moreover, the lengthy duration of the COVID-19 pandemic is also a lingering stressor in-and-of-itself, which may have prolonged consequences. $^{187}$

Various studies, conducted after the onset of the COVID-19 pandemic, have concluded that the pandemic has had a significant effect on the mental health of individuals in India, ${ }^{188}$ with some data suggesting that as many as $18-28 \%$ of the population are experiencing anxiety and depression, ${ }^{189}$ and more than $80 \%$ are perceived as needing mental health care. ${ }^{190}$ With the overstretched healthcare infrastructure, the fault-lines have been brought to the surface, especially in tertiary healthcare. ${ }^{191}$ Apart from the preexisting issues with the mental health legislative and policy framework, as discussed above, the lack of infrastructure, facilities, resources, and political will have deepened the furrows in the guarantee of this right during the COVID-19 pandemic.

In this part of the article, the authors analyse India's response to, and the efforts invested by it in guaranteeing the right to mental health during the COVID-19 pandemic. To illustrate the arguments, the authors map the impact of India's response to the pandemic on the mental health of two particular groups: healthcare/frontline workers and migrant workers. That the government has implemented policies haphazardly ${ }^{192}$ and taken actions/measures neglecting the mental health of all persons in a way that cuts across economic, social, and cultural lines, ${ }^{193}$ and particularly so of the vulnerable and marginalized in society, is evidenced by the two case-studies.

\section{Healthcare/frontline workers in India}

The COVID-19 pandemic has affected the health - physical as well as mental - of healthcare/frontline workers all across the world, ${ }^{194}$ and India is no exception. While dealing

\footnotetext{
${ }^{185}$ Nistula HEBBAR, "PM Modi Announces 21-Day Lockdown as COVID-19 Toll Touches 12" The Hindu (24 March 2020), online: The Hindu <https://www.thehindu.com/news/national/pm-announces-21-day-lockdownas-covid-19-toll-touches-10/article31156691.ece>.

186 “India to Ease Coronavirus Lockdown Despite Record New Cases" Al Jazeera (30 May 2020), online: Al Jazeera <https://www.aljazeera.com/news/2020/5/30/india-to-ease-coronavirus-lockdown-despite-record-new-cases>.

${ }^{187}$ Singh, Roy, Sinha, Parveen, Sharma, and Joshi, supra note 183; Dubey, Biswas, Ghosh, Chatterjee, Dubey, Chatterjee, Lahiri, and Lavie, supra note 183.

${ }^{188}$ Rajiv TANDON, “The COVID-19 Pandemic, Personal Reflections on Editorial Responsibility” (2020) 50 Asian Journal of Psychiatry 102100, cited in Anuraj Singh KOCHHAR, Ritasha BHASIN, Gulsheen Kaur KOCHHAR, Himanshu DADLANI, Viral Vijay MEHTA, Roseleen KAUR, and Charanpreet Kaur BHASIN, "Lockdown of 1.3 Billion People in India During COVID-19 Pandemic: A Survey of its Impact on Mental Health" (2020) 54 Asian Journal of Psychiatry 102213.

${ }^{189}$ Ravi Philip RAJKUMAR, "COVID-19 and Mental Health: A Review of the Existing Literature” (2020) 52 Asian Journal of Psychiatry 102066, cited in Kochhar, Bhasin, Kochhar, Dadlani, Mehta, Kaur, and Bhasin, supra note 188.

${ }^{190}$ Kochhar, Bhasin, Kochhar, Dadlani, Mehta, Kaur, and Bhasin, supra note 188.

191 Ibid.

${ }^{192}$ Human Rights Watch, “India: COVID-19 Lockdown Puts Poor at Risk” (27 March 2020), online: Human Rights Watch <https://www.hrw.org/news/2020/03/27/india-covid-19-lockdown-puts-poor-risk>.

${ }^{193}$ Debanjan BANERJEE and TS Sathyanarayana RAO, “'Unheard Voices of the Pandemic': Psychosocial Vulnerabilities of the Indian Migrant Population During COVID-19 Crisis” (2020) 36 Indian Journal of Social Psychiatry 84, online: Indian Journal of Social Psychiatry <https://www.indjsp.org/article.asp?issn=0971-9962; year $=2020$; volume $=36$; issue $=5$; spage $=84$; epage $=86$; aulast $=$ Banerjee $>$.

${ }^{194}$ WHO, "Attacks on Health Care in the Context of COVID-19" (30 July 2020), online: WHO <https://www.who. $\mathrm{int/news-room/feature-stories/detail/attacks-on-health-care-in-the-context-of-covid-19>;} \mathrm{Heather} \mathrm{HALL,} \mathrm{"The}$ Effect of the COVID-19 Pandemic on Healthcare Workers' Mental Health" (2020) 33 Journal of the American Academy of Physician Assistants 45.
} 
with the COVID-19 pandemic, healthcare/frontline workers have been at the forefront of an extremely stressful environment, triggered by the novelty of the disease, increased patient loads, unprecedented disruptions to normal life, high risk of exposure, ${ }^{195}$ inadequate resources including protective gear, lack of support, ${ }^{196}$ and concerns about the well-being of their families and friends. ${ }^{197}$ While no member of society has been immune to the impact of COVID-19, healthcare/frontline workers have been particularly exposed to various psychological stressors, while their mental health has been overlooked. ${ }^{198}$ Controlled studies conducted across the world, ${ }^{199}$ as well as those specific to the Indian landscape ${ }^{200}$ seem to suggest there is an extremely high prevalence of mental health concerns, such as depression, PTSD, burnout, anxiety, and insomnia among healthcare/frontline workers. ${ }^{201}$ Studies have also been indicative of different factors, ranging from biological, psychological, as well as socio-environmental as mediators of such concerns. Apart from the above-mentioned factors, lack of effective communication from the government, lack of resources, misinformation, unavailability of Personal Protective Equipment (PPE), and the stigma around the disease have also been identified as reasons for the development of mental health problems among healthcare/frontline workers in India. $^{202}$

Another aspect that haunts healthcare/frontline workers, especially in India, is violence, harassment, and ill-treatment, and as many as $75 \%$ of the doctors practicing in India have reported that they have faced such abuse, ${ }^{203}$ and this has increased substantially during the COVID-19 pandemic. $^{204}$ The reasons for the surge in the occurrence of such incidents against healthcare/frontline workers include anxiety, ignorance, and fear about the SARS CoV-2 virus - and the stigma of contracting it, ${ }^{205}$ as well as the

${ }^{195}$ Nishi SURYAVANSHI, Abhay KADAM, Gauri DHUMAL, Smita NIMKAR, Vidya MAVE, Amita GUPTA, Samyra R. COX, and Nikhil GUPTE, "Mental Health and Quality of Life Among Healthcare Professionals During the COVID-19 Pandemic in India" (2020) 10 Brain and Behaviour e01837.

${ }^{196}$ Kamlesh Kumari SHARMA, Ravneet KAUR, Muthuvenkatachalam SRINIVASAN, Siddharth SARKAR, Kalaivani MANI, Yamya SHARMA, and Sandhya GUPTA, "Impact of COVID-19 on Mental Health of Healthcare Professionals Working in COVID-19 Designated Clinical Areas in India” (2021) 8 International Journal of Community Medicine and Public Health 1406, online: International Journal of Community Medicine and Public Health <https://www.ijcmph.com/index.php/ijcmph/article/view/7686>.

${ }^{197}$ Jacob SHREFFLER, Jessica PETREY, and Martin HUECKER, "The Impact of COVID-19 on Healthcare Worker Wellness: A Scoping Review” (2020) 21 Western Journal of Emergency Medicine 1059.

198 Snehil GUPTA and Swapnajeet SAHOO, "Pandemic and Mental Health of the Front-Line Healthcare Workers:

A Review and Implications in the Indian Context Amidst COVID-19” (2020) 33 General Psychiatry e100284.

${ }^{199}$ Hall, supra note 194.

${ }^{200}$ Gupta and Sahoo, supra note 198.

${ }^{201}$ Department of Health and Family Welfare, Government of Karnataka and Department of Psychiatry, National Institute of Mental Health and Neurosciences, Bengaluru, "Caring for Health Care Warriors - Mental Health Support During COVID-19" (July 2020), online: Ministry of Health and Family Welfare, <https://www. mohfw.gov.in/pdf/HCWMentalHealthSupportGuidanceJuly20201.pdf>.

202 Ibid.

${ }^{203}$ Mukul Chandra KAPOOR, "Violence Against the Medical Profession" (2017) 33(2) Journal of Anaesthesiology Clinical Pharmacology 145, cited in Karthikeyan P. IYENGAR, Vijay Kumar JAIN, and Raju VAISHYA, "Current Situation with Doctors and Healthcare Workers During COVID-19 Pandemic in India" (2020) Postgraduate Medical Journal 1.

${ }^{204}$ Iyengar, Jain, and Vaishya, supra note 204.

205 "Covid-19: Indian Government Vows to Protect Healthcare Workers from Violence Amid Rising Cases" BMJ (23 April 2020), online: BMJ <https://www.bmj.com/content/369/bmj.m1631>; Ari ALSTEDTER, Bhuma SHRIVASTAVA, and Dhwani PANDYA, "Doctors, Hospital Workers are Also Fighting Abuse and Violence as Virus Stigma, Panic Grows" ThePrint (14 April 2020), online: ThePrint <https://theprint.in/india/doctors-hospital-workers-are-also-fighting-abuse-and-violence-as-virus-stigma-panic-grows/401144/>. 
augmentation of these worries due to misinformation and misplaced quotes proliferating over social media. ${ }^{206}$ The increase in the number and gravity of such incidents, which have ranged across the spectrum of aggressive emotional responses by the relatives of patients, verbal attacks, physical violence, and even serious manhandling and murder of healthcare/frontline workers, ${ }^{207}$ may also be attributed to the inaccessibility of medical aid due to the over-inundation of the public health machinery and the restriction on nonemergency admissions to private hospitals, transport suspension during the lockdown, and the boiling-over of people's frustration with the quarantine and containment zone restrictions. ${ }^{208}$ Being cast into the role of the "newer untouachables"209 - together with the potent combination of exposure to trauma and violence, impediments to the fulfilment of their duties by the inadequate infrastructure and administrative restrictions, and neglect for their well-being - have detrimentally impacted the mental health of healthcare/frontline workers. ${ }^{210}$

The attainment of the highest standards of mental health and well-being, particularly for healthcare/frontline workers, is an important factor in a State's successful effort towards preparedness, response, and recovery during demanding situations or crises, such as the pandemic. ${ }^{211}$ It is pivotal for States to realize that being cognizant of and investing in mental healthcare services is key to the ability of healthcare/frontline workers to perform effectively in a sustained manner in the long term, and to assist them in dealing with the pressures of their jobs in particularly demanding times. While the WHO has emphasized the role of governments, the international community, and civil society in protecting healthcare professionals by addressing attacks on health systems, ${ }^{212}$ as well as made available a risk communication and community engagement (RCCE) guidance, the obligation lies with States to accord these issues priority, and to mainstream mental health as a human right within these action plans.

Notably, the government of India has attempted to address the harassment and violence against healthcare professionals by introducing an Ordinance ${ }^{213}$ titled the Epidemic Diseases (Amendment) Ordinance 2020, which penalizes such attacks. ${ }^{214}$ This is a proactive and positive step on the part of the Indian government to address one of the contributors to the deterioration of mental health for healthcare professionals, and is a step in pursuance of the international standards outlined in the earlier parts of this article. It also reinforces the good practices identified by the WHO as pivotal for States to uphold and implement in the context of attacks on healthcare workers during the pandemic. ${ }^{215}$ Since the Ordinance has come into force, fewer acts of violence have

\footnotetext{
${ }^{206}$ Donna MCKAY, Michele HEISLER, Ranit MISHORI, Howard CATTON, and Otmar KLOIBER, “Attacks Against Health-Care Personnel Must Stop, Especially as the World Fights COVID-19" (2020) 395(10239) The Lancet 1743.

${ }^{207}$ Iyengar, Jain, and Vaishya, supra note 204; Kapoor, supra note 204; Kanjaksha GHOSH, "Violence Against Doctors: A Wake-Up Call” (2018) 148 Indian Journal of Medical Research 130.

${ }^{208}$ Iyengar, Jain, and Vaishya, supra note 204.

209 Ibid.

${ }^{210}$ Seshadri Sekhar CHATTERJEE, Madhushree CHAKRABARTY, Debanjan BANERJEE, Sandeep GROVER, Shiv Sekhar CHATTERJEE, and Utpal DAN, "Stress, Sleep and Psychological Impact in Healthcare Workers During the Early Phase of COVID-19 in India: A Factor Analysis” (2021) Frontiers in Psychology, online: Frontiers in Psychology <https://www.frontiersin.org/articles/10.3389/fpsyg.2021.611314/full>.

${ }^{211}$ United Nations, supra note 79.

${ }^{212}$ WHO, "Attacks on Health Care in the Context of COVID-19", supra note 194.

${ }^{213}$ Epidemic Diseases (Amendment) Ordinance, 2020, online: PRS Legislative Research <https://prsindia.org/ billtrack/the-epidemic-diseases-amendment-ordinance-2020>.

214 "Cabinet Clears Ordinance to Punish Violence Against Health Workers, IMA Withdraws Protest" The Wire (22 April 2020), online: The Wire <https://thewire.in/rights/coronavirus-ordinance-health-workers-ima>.

${ }^{215}$ WHO, "Attacks on Health Care in the Context of COVID-19", supra note 194.
} 
been reported - proving the use of stringent legislation in the protection of healthcare workers. $^{216}$

However, the present legislative and policy framework is inadequate to address the vast range of concerns pertaining to mental health, or the long-term impact of these concerns, especially when they go unaddressed or are excessively pathologized when addressed. The recent recognition by the Supreme Court of India in Re: Essential Supplies Matter ${ }^{217}$ that: $^{218}$

[i]t is absolutely necessary to take urgent steps for their (healthcare professionals, as inclusive of doctors, nurses, healthcare workers, laboratory technicians, ward staff, ambulance drivers, crematorium workers etc.) well-being to ensure that our appreciation for their tremendous efforts is not reduced to rhetoric ... should ideally urge the government to frame holistic policies, which reflect the "whole person" approach in guaranteeing the well-being of healthcare/frontline workers.

Moreover, as important as it is for legislative measures to be enacted, policies to be framed, and impactful decisions to be adjudicated, it is equally important for the government and policymakers to generate awareness of the psychological problems faced by healthcare/frontline workers, urge these workers to avail themselves of help during such times, and to make available the adequate infrastructure for it. For instance, telecounselling for psychological distress should be made available to healthcare/frontline workers in India - controlled trials have indicated their effectiveness. ${ }^{219}$ Similarly, the government should urge hospitals, and particularly public hospitals, wherein healthcare/frontline workers are reported as suffering from "acute helplessness" and "mental turmoil", ${ }^{220}$ to draft and implement action plans, strategies, and policies for the workplace to address the impact of psychological problems faced by these workers.

\section{Migrant workers in India}

It has been remarked that "[t]he treatment given to migrants by the State conveys the nation's value". ${ }^{221}$ In India, migration is often induced by factors such as unemployment, family movement, impoverishment, regional disparities, and calamities, ${ }^{222}$ which varies with the degree of diversity in different areas, people, intervening obstacles, and fluctuations and checks in the economy. ${ }^{223}$ As of 2020 , it is estimated that there are 600 million internal migrants ${ }^{224}$ of which one-third are inter-state and inter-district migrants. Within

\footnotetext{
${ }^{216}$ Mathew A. MANOJ, Jagadish Rao PADUBIDRI, Jsrg SARAN, Sowmya J. RAO, B Suresh Kumar SHETTY, and Haneil D' SOUZA, "Violence Against Healthcare Personnel in India: COVID-19 Prompts Stricter Laws" (2021) Medico-Legal Journal.

${ }^{217}$ Re: Essential Supplies and Services During Pandemic, Supreme Court of India, Order dated 30 April 2021, Suo Motu Writ Petition (Civil) No.3 of 2021, at paras. 65-8.

${ }^{218}$ Ibid., para. 65.

${ }^{219}$ Snehil GUPTA, Mohit KUMAR, Abhijit R. ROZATKAR, Devendra BASERA, Shashank PURWAR, Disha GAUTAM, and Rahat JAHA, "Feasibility and Effectiveness of Telecounseling on the Psychological Problems of Frontline Healthcare Workers Amidst COVID-19: A Randomized Controlled Trial from Central India” (2021) 43 Indian Journal of Psychological Medicine 343.

${ }^{220}$ Chatterjee, Chakrabarty, Banerjee, Grover, Chatterjee, and Dan, supra note 211.

${ }^{221}$ Catherine DAUVERGNE, "Sovereignty, Migration and the Rule of Law in Global Times" (2004) 67(4) The Modern Law Review 588, as cited in Shailendra KUMAR and Sanghamitra CHOUDHURY, "Migrant Workers and Human Rights: A Critical Study on India's COVID-19 Lockdown Policy” (2021) 3 Social Sciences \& Humanities Open 100130.

${ }^{222}$ Kumar and Choudhury, supra note 222.

${ }^{223}$ Everett S. LEE, “A Theory of Migration” (1966) 3 Demography 47.

${ }^{224}$ Surojit GUPTA, “30\% of Migrants Will Not Return to Cities: Irudaya Rajan” The Times of India (1 June 2020), online: The Times of India <https://timesofindia.indiatimes.com/india/30-of-migrants-will-not-return-to-citiesirudaya-rajan/articleshow/76126701.cms> cited in S. Irudaya RAJAN, P. SIVAKUMAR, and Aditya SRINIVASAN,
} 
this 200 million, two-thirds are estimated to be migrant workers (approximately 140 million). ${ }^{225}$ While a specific law has been promulgated to protect and safeguard the interests and rights of Indian migrant workers, ${ }^{226}$ there are also laws which protect the interests and rights of workers generally. ${ }^{227}$ However, because the majority of migrant workers work in the "informal" sector, wherein the implementation of these laws is lacking, they are often exploited, and are completely dependent on the mercy of their employers and contractors. ${ }^{228}$ These impediments to accessing the protective legal framework are compounded by social marginalization, the strenuous nature of their work, and instances of verbal and/or physical abuse, which result in "low-life conditions". ${ }^{229}$

Studies have evinced that a combination of these factors, alongside the separation of these workers from their families, have implications for the workers' mental health, as these factors precipitate an increase in serious anxiety disorders, psychotic breakdowns, and post-traumatic disorders. ${ }^{230}$ Migrant workers represent a group of persons in Indian society who are particularly vulnerable. When their interests and rights have been the subject of legislation, the perspective trained on these instruments has been one that divorces economic rights from civil rights, such as the right to a life of dignity and liberty. The right to health, postured primarily as an economic right, has been treated no differently. Consequently, migrant workers have been among the worst victims of the pandemic in India, ${ }^{231}$ and the government's neglect for their concerns has been illustrative of the mirage of the nation's values and the importance accorded to human rights. ${ }^{232}$

\footnotetext{
“The COVID-19 Pandemic and Internal Labour Migration in India: A “Crisis of Mobility” (2020) 63 The Indian Journal of Labour Economics 1021.

${ }^{225}$ Ibid.

${ }^{226}$ Inter-State Migrant Workmens Act, 1979 and Inter-State Migrant Workmen (ISMW Regulation of Employment \& Conditions of Services) Central (Amendment) Rules, 2017.

${ }^{227}$ Kumar and Choudhury, supra note 222:
}

The other important Indian laws meant to protect the interest of workers include: the Trade Union Act, 1926 that defines law related to registration of trade unions and provisions related to registered trade unions; the Payment of Wages Act, 1936 which ensures that wages be paid in cash and not in kind to employed persons within the prescribed time limit; the Industrial Dispute Act, 1947 which provides for the investigation and settlement of industrial disputes; the Minimum Wages Act, 1948 which provides for fixing minimum wage rates in certain employments; the Payment of Bonus Act, 1965 which provides for payment of minimum bonus of $8.33 \%$ of salary to workers working in enterprises employing 20 or more people; the Contract Labor (Regulation and Abolition) Act, 1970 which regulates the employment of contract labor in certain establishments and to provide for its abolition in certain circumstances and for matters connected therewith; the Equal Remuneration Act, 1976 which provides for payment of equal remuneration to men and women; the Child Labor (Prohibition and Regulation) Act, 1986 which prohibits children under 14 years of age from being employed in certain work; the Unorganized Workers Social Security Act, 2008 which provides for social security and the welfare of unorganized workers; the Maternity (Amendment) Bill, 2017 which provides for 26 weeks of paid maternity leave to women employees who have worked in an establishment for at least 80 days in past 12 months; and the Mahatma Gandhi National Rural Employment Guarantee Act, 2005 which provides for 100 days of guaranteed employment in every financial year to unskilled workers in rural India.

${ }^{228}$ Kumar and Choudhury, supra note 222.

${ }^{229}$ Nicola MUCCI, Veronica TRAVERSINI, Gabriele GIORGI, Eleonora TOMMASI, Simone DE SIO, and Giulio

ARCANGELI, “Migrant Workers and Psychological Health: A Systematic Review” (2020) 12 Sustainability 120.

230 Ibid.

${ }^{231}$ Sudarshan R. KOTTAI, "Migrant Workers and the Politics of Mental Health" (2020) 55(31) Economic and Political Weekly 39.

${ }^{232}$ Ibid. 
Internal migrants had to travel thousands of kilometres on foot during the hastily implemented nationwide lockdown in $2020,{ }^{233}$ after being given only a four-hour notice. Their journey was one in which they were stigmatized at both end-points, ${ }^{234}$ and were excluded from accessing healthcare, legal remedies, and the fulfilment of their rights. ${ }^{235}$ They were surveilled while charting their journey, several lost family members, ${ }^{236}$ and the failure of the government machinery to ensure for these workers food, shelter, means of transport, ${ }^{237}$ and other basic amenities further widened the trust deficit. ${ }^{238}$ The absence of a coherent policy concerning their movement, or the accommodations required by virtue of it, and the exacerbation of pre-existing vulnerabilities due to the absence of an emphasis on family and care groups, ${ }^{239}$ alongside the toll of the journey, fear of discrimination, and uncertainty about income have had a grave impact on the mental health of migrant workers. ${ }^{240}$ Furthermore, the widespread prevalence of pre-existing physical health conditions, such as occupational pneumoconiosis, tuberculosis, human immunodeficiency virus, and pollution-related diseases among migrant workers in India, ${ }^{241}$ amidst conditions of inaccessibility to healthcare services and worries about infecting loved ones, has converted the risks of contracting the virus into a choice between life and livelihood for many of these workers, thereby leading to further immiseration. The reinforcement of inequalities and vulnerabilities plaguing the lives of migrant workers during the pandemic, without sufficient attention paid to the implications for their mental health and well-being, reflects the low priority accorded to the psychosocial needs of the vulnerable in India. ${ }^{242}$

Though, belatedly, it is worth noting that the Ministry of Home Affairs has urged State governments to provide food, shelter, and medical and psychological assistance to migrant workers. ${ }^{243}$ In pursuance of this objective, various state governments have undertaken programs with the endeavour of addressing the issues of depression, anxiety, apprehension, and sleeplessness caused by the lockdown among migrant workers. ${ }^{244}$ However,

233 "In Pictures: The Long Road Home for India's Migrant Workers" Al Jazeera (22 April 2020), online: Al Jazeera <https://www.aljazeera.com/gallery/2020/4/22/in-pictures-the-long-road-home-for-indias-migrant-workers>;

Press Trust of India, “Migrant Woes “Greatest Manmade Tragedy' in India Since Partition: Ramchandra Guha” The Hindu (24 May 2020), online: The Hindu <https://www.thehindu.com/news/national/migrant-woes-greatestmanmade-tragedy-in-india-since-partition-ramchandra-guha/article31663219.ece>.

${ }^{234}$ Banerjee and Rao, supra note 193.

235 Ibid.

${ }^{236}$ Ibid; A Arjan DE HAAN, "Labour Migrants During the Pandemic: A Comparative Perspective” (2020) 63 The Indian Journal of Labour Economics 885; Alasdair PAL and Danish SIDDIQUI, "The Long Road Home: India's Migrant Workers Fall Through the Cracks of the Coronavirus Crisis" Reuters (21 April 2020), online: Reuters $<$ https://www.reuters.com/investigates/special-report/health-coronavirus-india-migrants/>.

${ }^{237}$ Kottai, supra note 232.

${ }^{238}$ Rajan, Sivakumar, and Srinivasan, supra note 225.

${ }^{239}$ Ranjana CHOUDHARI, "COVID-19 Pandemic: Mental Health Challenges of Internal Migrant Workers of India” (2020) 54 Asian Journal of Psychiatry 102254; Rajan, Sivakumar, and Srinivasan, supra note 225.

${ }^{240}$ Rajan, Sivakumar, and Srinivasan, supra note 225; Choudhari, supra note 241.

241 Ibid.

242 Choudhari, supra note 241.

243 Deeptiman TIWARY, "Provide Counselling to Migrants: Centre to States" The Indian Express (13 April 2020), online: The Indian Express <https://indianexpress.com/article/india/coronavirus-india-lockdown-provide-counselling-to-migrants-centre-to-states-6359601/>.

${ }^{244}$ Reena SOPAM, "In Bihar, 14,000 Migrants Seek Counselling to Overcome Lockdown Blues" Hindustan Times (18 July 2020), online: Hindustan Times <https://www.hindustantimes.com/india-news/in-bihar-14-000migrants-seek-counselling-to-overcome-lockdown-blues/story-jxQmhahb6CU0gpqKN5jjkL.html>; the State of Karnataka as described in Rakesh CHANDER, Manisha MURUGESAN, Daniel RITISH, Dinakaran DAMODHARAN, Vikram ARUNACHALAM, Rajani PARTHASARATHY, Aravind RAJ, Manoj Kumar SHARMA, Narayana MANJUNATHA, Suresh Bada MATH, and Channaveerachari Naveen KUMAR, "Addressing the Mental Health 
critics of such programs advocate for a more ecologically valid intervention, i.e., one which seeks to address the systemic failures rather than one which acts as a stop-gap or regresses to reliance on pharmaceuticals. Further, an overhaul of the public health response to disaster management by way of an amendment to the Epidemic Diseases Act 1897, in a way which integrates psycho-social equality, mental health interventions, and the identification of "at-risk populations" ${ }^{245}$ as being inclusive of migrant workers has also been advocated in furtherance of the goal of addressing the manifold concerns systemically. In recognition of the interlinkages between an array of rights, there is also a need to increase access to social protection in light of the exclusion of informal workers so as to reduce their inherent vulnerabilities. ${ }^{246}$

A holistic intervention is the need of the hour, for failure to do so threatens the development of "severe, acute and chronic, adverse mental health consequences due to [the] COVID 19 pandemic [], many [of which are] acting concurrently to cause physical, mental, and socio-economical adversities" ${ }^{247}$ among migrant workers. In order for the intervention to be effective, it is essential the government recognize that all human beings, particularly the vulnerable such as the migrant workers, are entitled to have certain innate and inalienable rights upheld. Resorting to the tool of human rights and harmonizing the domestic framework with the international legal framework can thus be a powerful means of preventing a further deterioration in the living conditions of migrant workers or an amplification of their vulnerabilities, and can also offer them a protective and remedial framework. By channelling the rights-based approach, applying it to mental health, and demanding that India abide by its international obligations it is hoped that the resultant placement shall be that of the "political at the heart of the psychological and the psychological at the heart of the political".

\section{A Possible Way Forward}

The discussion mapped in the foregoing part of this article showcases how "[t]he Covid-19 crisis did not create new shortcomings, [but rather] laid bare the existing shortcomings that have plagued the mental health system for years." ${ }^{248}$ These shortcomings span a wide range of issues, such as: the limited applicability of general laws pertaining to mental health to impairments which are not substantial or long term; the meagre attention devoted to mental health in regulatory frameworks specific to vulnerable groups in society; the lacklustre implementation of promulgated laws; excessive pathologization of the issue; the absence of an integrated mental healthcare system and appropriate infrastructure; insufficient attentiveness to sensitization measures; and the inadequate emphasis on programs and policies suited to the country context. Each of these shortcomings is also reflective of the placement of mental health in the bottom tier of the hierarchy of priorities ascertained by States, given the incongruence between the resources required and the availability of scarce resources from within the total healthcare budget allocated to mental health. ${ }^{249}$ The dismal harmonization of domestic legal and policy perspectives on mental health with the non-derogable nature of the right and the obligations to

Concerns of Migrant Workers During the COVID-19 Pandemic: An Experiential Account" (2020) International Journal of Social Psychiatry 826.

${ }^{245}$ Banerjee and Rao, supra note 193.

${ }^{246}$ Rajan, Sivakumar, and Srinivasan, supra note 225.

${ }^{247}$ Choudhari, supra note 241.

${ }^{248}$ Dastidar, supra note 173, quoting Soumitra Pathare, Director of the Centre for Mental Health Law and Policy.

${ }^{249}$ Goyal, supra note 174 . India spends $0.05 \%$ of its total healthcare budget on mental healthcare annually. In comparison, developed countries spend $4-5 \%$ on an annual basis. 
progressively realize it as per the international framework is the overarching shortcoming, which has been laid bare by the COVID-19 pandemic.

The groups identified in the foregoing part thus act as instantiations of the manner in which the pandemic has implicated and compounded pre-existing vulnerabilities and inequalities, particularly among the marginalized, ${ }^{250}$ and adversely affected the right to mental health as well as a wide array of rights intrinsically connected to mental health and well-being. More generally, as evidenced by a study published in the Indian Journal of Psychiatry, an increasing number of persons in India have been susceptible to the development of and/or deterioration of pre-existing mental illnesses. ${ }^{251}$ This is due to the "stress multiplier"252 effect of the pandemic in India, attributable to the stringency of the lockdowns imposed by the government, the accompanying suspension of movement and economic activity, and the negative emotions associated with the resultant isolationism, alongside a failure to ensure avenues for support or redress for those most affected or in need. ${ }^{253}$ Pertinently, stop-gap measures to address certain concerns magnified by the COVID-19 pandemic, as introduced by the Indian government, are insufficient responses to the short- and long-term implications of the pandemic on the mental health of individuals, or to the structural inequalities characterizing the Indian society. In the forthcoming paragraphs, the authors attempt to outline a possible way forward.

In the short term, there is a need for the government to mainstream considerations of mental health and well-being into its plans for relief, response, and protection during the pandemic, and to make available support structures and facilities specifically for the vulnerable and the marginalized. It is also pivotal for the government to analyse the feasibility and benefits of a community-based model of implementing plans, to avail the assistance of stakeholders, such as civil society organizations engaged with mental health policy, in the processes of introducing and implementing decisions during the pandemic, as well as ensure a thorough periodic review of any pandemic-specific policies by including among its considerations the right to mental health as well as its interlinkages with other human rights. Further, given the constraints of movement during the pandemic, the efforts towards disseminating information about the need to care for one's mental wellbeing should also be accompanied by information about online counselling services at hospitals and community healthcare centres, ${ }^{254}$ as well as at psychology departments

\footnotetext{
${ }^{250}$ Justin PICKARD, Shilpi SRIVASTAVA, Lyla MEHTA, and Mihir R. BHATT, "In Focus: COVID-19, Uncertainty, Vulnerability and Recovery in India" (November 2020), online: Social Science in Action <https://www.socialscienceinaction.org/resources/covid-19-uncertainty-vulnerability-and-recovery-in-india/>.

${ }^{251}$ Sandeep GROVER, Swapnajeet SAHOO, Aseem MEHRA, Ajit AVASTHI, Adarsh TRIPATHI, Alka SUBRAMANYAN, Amrit PATTOJOSHI, G Prasad RAO, Gautam SAHA, KK MISHRA, Kaustav CHAKRABORTY, Naren P. RAO, Mrugesh VAISHNAV, Om Prakash SINGH, PK DALAL, Rakesh K. CHADDA, Ravi GUPTA, Shiv GAUTAM, Siddharth SARKAR, TS Sathyanarayana RAO, Vinay KUMAR, and YC Janardran REDDY, "Psychological Impact of COVID-19 Lockdown: An Online Survey from India" (2020) 62 Dental Science 354, online: Indian Journal of Psychiatry <https://www.indianjpsychiatry.org/article.asp?issn=0019-5545;year=2020; volume= 62 ; issue $=4$; spage $=354$; epage $=362$; aulast $=$ Grover $>$.

252 Ibid.

${ }^{253}$ Ashish KOTHARI, “The Various Avatars of Self-reliance” Wall Street International (13 July 2020), online: Wall Street International <https://wsimag.com/economy-and-politics/62759-the-various-avatars-of-self-reliance>; Debraj RAY and S. SUBRAMANIAN, "India's Lockdown: An Interim Report", National Bureau of Economic Research, Working Paper No. 27282, May 2020, at 70, online: National Bureau of Economic Research <https:// www.nber.org/system/files/working_papers/w27282/w27282.pdf>; Pickard, Srivastava, Mehta, and Bhatt, supra note 255 .

${ }^{254}$ Sarah L. KOPELOVICH, Maria MONROE-DEVITA, Benjamin E. BUCK, Carolyn BRENNER, Lorna MOSER, L. Fredrik JARSKOG, Steve HARKER, and Lydia A. CHWASTIAK, "Community Mental Health Care Delivery During the COVID-19 Pandemic: Practical Strategies for Improving Care for People with Serious Mental Illness" (2020) 57 Community Mental Health Journal 405.
} 
of several universities, ${ }^{255}$ so that individuals do not have to choose between physical and mental well-being, and to know they can avail options which help them prioritize both. Additionally, the thirty-one-point guidance issued by the WHO for preventing, as well as mitigating, anxiety, depression, and stigma ${ }^{256}$ should also be adapted to, and operationalized in, the Indian context.

The success of these measures, even if taken by India during the COVID-19 pandemic, shall be limited unless they are preceded by the recognition that mental health is a human rights concern as opposed to solely a medical concern. ${ }^{257}$ There is also a need for the regulatory framework to be rethought in a manner that accounts for the oft-episodic, dynamic, and fluctuating nature ${ }^{258}$ of mental health concerns, the applicability of which is extended to ensure support for persons whose concerns are neither substantial nor long term. Given that facets of the right to mental health impose a non-derogable obligation on States, and the interdependency of mental health with physical health as well as other human rights, legislative as well as other measures need to be introduced/amended and effectively implemented by India in order for it to "respect-protect-fulfil" the negative and positive obligations attached to the right, and to facilitate access in a non-discriminatory manner to the array of resources and supports pivotal to mental health and well-being. ${ }^{259}$ It is equally pertinent for India to expend efforts towards the elimination of stigma attached to persons suffering from mental illnesses, ${ }^{260}$ to invest in the training of personnel and care-workers in institutions, and to establish a multi-stakeholder participatory model for the implementation of the measures taken by it. In particular, there is also a need for States to allocate resources to community-based approaches ${ }^{261}$ instead of tertiary psychiatric hospitals, as the benefits of such approaches are more cost-effective, are strongly supported by empirical research, and are also recognized as good practices by the United Nations, ${ }^{262}$ and the task force which authored the National Mental Health Report, 2019. ${ }^{263}$ Movement towards the rights-based model of mental health, ${ }^{264}$ which accords due importance to the role of the community in letter, spirit, and practice is likely to address the concerns of individuals with mental health concerns in a more meaningful manner.

\section{An Urgent Call for Global Action}

India is not alone as an example of the shortcomings of mental healthcare systems laid bare by the COVID-19 pandemic. As much is encapsulated in Ingrid Daniels' words, as

\footnotetext{
${ }^{255}$ Shuai LIU, Lulu YANG, Chenxi ZHANG, Yu-Tao XIANG, Zhongchun LIU, Shaohua HU, and Bin ZHANG, "Online Mental Health Services in China During the COVID-19 Outbreak" (2020) 7 The Lancet Psychiatry e17, online: The Lancet <https://www.thelancet.com/journals/lanpsy/article/PIIS2215-0366(20)30077-8/fulltext>.

${ }^{256}$ WHO, "Mental Health and Psychosocial Considerations During the COVID-19 Outbreak" (18 March 2020), online: WHO <https://www.who.int/docs/default-source/coronaviruse/mental-health-considerations.pdf>.

${ }^{257}$ See Mental Health Care Act, 2017; Right of Persons with Disabilities Act, 2016.

${ }^{258}$ Math, Gowda, Basavaraju, Manjunatha, Kumar, Philip, and Gowda, supra note 182.

${ }^{259}$ ICESCR, art. 12.

${ }^{260}$ Amresh SHRIVASTAVA, Avinash DE SOUSA, and Pragya LODHA, "Research Progress in the Understanding and Implications of Stigma Related to Mental Health" (2018) 2 Annals of Indian Psychiatry 93.

${ }^{261}$ UN Doc. A/HRC/34/32 (2017), supra note 16 at paras. 9, 11, 19; Asanbe, Gaba, and Yang, supra note 7; The Hans Foundation, "National Strategy For Inclusive and Community Based Living for Persons with Mental Health Issues" (2019), online: The Hans Foundation <http://thehansfoundation.org/wp-content/uploads/2020/07/THFNational-Mental-Health-Report-Final.pdf>; Kopelovich, Monroe-Devita, Buck, Brenner, Moser, Jarskog, Harker, and Chwastiak, supra note 259.

${ }^{262}$ United Nations, supra note 79; The Hans Foundation, supra note 266.

${ }^{263}$ The Hans Foundation, supra note 266.

${ }^{264}$ Gooding, supra note 53 at 47.
} 
quoted in the briefing titled "The Impact of COVID-19 on Global Mental Health", authored by the WHO and UN agencies: ${ }^{265}$

The extraordinary increase in mental health needs is taking its toll on already burdened mental health services which are under-funded and under-resourced in many countries on every continent affected by the COVID-19 pandemic. COVID-19 has exposed the serious gaps in mental health care, and now more than ever world leaders need to prioritise and ensure that quality mental health support is accessible to everyone, everywhere.

As much in the global context as in the Indian context, then, the COVID-19 pandemic has made it amply clear that the mere existence of international human rights standards, norms, and laws in international treaties, global commitments, and authoritative guidance does not necessarily result in the effective fulfilment of human needs and wants, ${ }^{266}$ particularly for the enforcement of economic, social, and cultural rights. ${ }^{267}$ The claim put forth by States is that the international obligations in respect of economic, social, and cultural rights do not guarantee immediate realization at the domestic level, but are rather to be "progressively realized". ${ }^{268}$ Justifications for the gradual pace of fulfilment of such rights include factors such as the differential stages of States' development, their distinctive contexts, and prioritization of resources as per nation-specific policies.

The issue becomes even more profound with respect to the right to mental health as the scarce resources available in most States are predominantly allocated to physical health, resulting in an artificial bifurcation and hierarchization between physical and mental health. The ramifications of such a bifurcation have intensified globally during this pandemic. Much like in India, the pandemic has revealed the lacunae in guaranteeing the right to mental health globally due to the lack of cohesive policies which mainstream the right to mental health, the lacklustre implementation of promulgated laws and policies, and the discrepancies in the practice associated with the "respect-protect-fulfil" obligations attached to the right and imposed on States. It has also amplified these concerns due to the continued neglect meted out to mental health, amidst practices detrimental for mental health and well-being, thereby necessitating a collective and urgent call for action.

While these outcomes of the pandemic seem to spell irredeemable disaster, ${ }^{269}$ they are instead excruciating reminders of the need for States to recognize the non-derogable facets of the right to mental health, as well as the overdue need for reform in the manner in which mental health is addressed by them. ${ }^{270}$ Understood through this lens, the promise of international human rights law helps in setting the tone by highlighting the urgent

\footnotetext{
${ }^{265}$ United for Global Mental Health, “The Impact of COVID-19 on Global Mental Health: A Brief” (2020) at 2 citing Ingrid Daniels, online: United for Global Mental Health < https://unitedgmh.org/sites/default/files/202009/The\%2BImpact\%2BOf\%2BCovid-19\%2BOn\%2BGlobal\%2BMental\%2BHealth\%2BReport.pdf>.

${ }^{266}$ Wiktor OSIATYŃSKI, Human Rights and their Limits (Cambridge: Cambridge University Press, 2009).

${ }^{267}$ Ontario Human Rights Commission, "Social, Cultural and Economic Rights under International Law", online: Ontario Human Rights Commission <http://www.ohrc.on.ca/en/human-rights-commissions-and-economic-and-social-rights/social-cultural-and-economic-rights-under-international-law>.

${ }^{268}$ ICESCR, art. 2(1).

${ }^{269}$ Krešimir ĆOSIĆ, Siniša POPOVIĆ, Marko ŠARLIJA, and Ivan KESEDŽIĆ, "Impact of Human Disasters and COVID-19 Pandemic on Mental Health: Potential of Digital Psychiatry” (2020) 32 Psychiatria Danubina 25.

${ }^{270}$ Jennifer OROILIDIS, "The COVID-19 Pandemic Has Become a Painful Reminder of How Poor Mental Health Provision is" EuroNews., (14 April 2020), online: EuroNews <https://www.euronews.com/2020/04/14/the-covid19-pandemic-has-become-a-painful-reminder-how-poor-mental-health-provision-view>.
} 
need to prioritize mental health as a human right, given its possibly disastrous short and long-term implications for individuals as well as societies. ${ }^{271}$ By treating the Indian experience detailed in the foregoing part as a core global reference for the pivotal role human rights can and should play in policy-making at the domestic level, this segment outlines recommendations for States to consider effectuating amid, as well as in the aftermath of, the pandemic.

Firstly, it bears recognition that legislation has an important role to play in the articulation and protection of the rights of individuals, especially the right to mental health. ${ }^{272}$ However, as is evident from the Indian regulatory framework, it is imperative for legislators to emphasize the harmonization between the international and domestic frameworks, as well as the synchronization between various domestic instruments pertaining to the right to mental health. In particular, while harmonizing the international and domestic frameworks, it is imperative for States to ensure the integration of the progressive interpretations of the right to health, notably through the jurisprudence developed by the CESCR and the standards enumerated within the UNCRPD. Moreover, given that black letter of law must be accompanied by effective implementation, an outcome which requires the cooperation of various actors and stakeholders, ${ }^{273}$ as well as the recognition of interlinkages between mental health and other rights, it is imperative for the judicial authorities of States to adopt a proactive stance towards issues pertaining to mental health and well-being. Measures which facilitate a "paradigm shift" 274 in the societal attitudes towards persons grappling with mental health concerns, and which destigmatize availing help for such concerns, must also be undertaken by a range of actors and stakeholders - the executive, civil society organizations, academics, the media, and others. Putting these recommendations into action is likely to have a positive impact on the robustness with which the right to mental health is guaranteed across global and local landscapes, as well as on the future preparedness for other global crises.

Secondly, much like in India, it is worth recognizing that the global impact of the pandemic has not been uniform, ${ }^{275}$ and that certain vulnerable groups of persons in society have been rather disproportionately affected by it. Moving forward, it is imperative for States to recognize the pre-existing vulnerabilities of certain groups of persons, to attend to the amplification of these vulnerabilities during the pandemic, and to be cognizant of the intersections of such vulnerabilities with the deterioration of individuals' mental health, especially as the likelihood of the lingering and long-term effects of the pandemic looms large on the horizon.

For instance, healthcare/frontline workers represent a group of persons whose mental health has been adversely affected by the pandemic globally. ${ }^{276}$ Studies indicate the prevalence of mental health concerns such as anxiety, depression, and PTSD among these workers due to their increased workload, exposure to grief and loss, fear of infection, inadequate rest, lack of PPE, informational overload, growing isolationism due to

\footnotetext{
${ }^{271}$ Roger MAGNUSSON, Advancing the Right to Health: The Vital Role of Law (Geneva: World Health Organization, 2017), online: WHO <https://www.who.int/healthsystems/topics/health-law/health_law-report/en/>; Brendan D. KELLY, "Emergency Mental Health Legislation in Response to the Covid-19 (Coronavirus) Pandemic in Ireland: Urgency, Necessity and Proportionality” (2020) 70 International Journal of Law and Psychiatry 101564.

272 Magnusson, supra note 277.

${ }^{273}$ Rachel JENKINS, Florence BAINGANA, Raheelah AHMAD, David MCDAID, and Rifat ATUN, "Social, Economic, Human Rights and Political Challenges to Global Mental Health" (2011) 8 Mental Health in Family Medicine 87.

${ }^{274}$ Cameron, supra note 50.

${ }^{275}$ UN Doc. E/C.12/2020/1 (2020), supra note 123.

${ }^{276}$ António GUTERRES, "We Need to Take Action to Address the Mental Health Crisis in This Pandemic" Time (21 May 2020), online: Time <https://time.com/5839553/un-action-mental-health-crisis/>.
} 
separation from their families, and lack of safety measures. ${ }^{277}$ In the short term, it is imperative for States to encourage the establishments at which these workers are engaged to provide regular support, care, and training for deteriorating mental health, ${ }^{278}$ to mandate and enforce work-rotation schedules and the availability of PPE, ${ }^{279}$ and to commence a temporally definite process of collecting disaggregated data to identify the particular needs of workers performing different roles within this group. ${ }^{280}$ In the long term, through legislative measures, judicial proactivity, and targeted interventions, States should ensure the continued provision of adequate support for the mental healthcare of these workers, the destigmatization of the risks associated with the roles of these workers, the participation of these workers in the framing of new policies and programs, the allocation of funds for future preparedness, and attempts towards harnessing new technologies to attain these ends. ${ }^{281}$

Migrant workers, in whom the incidence of psychotic, anxiety, and post-traumatic disorders has been reported to be on the rise ${ }^{282}$ are another group of persons whose mental health is at risk, which States need to ensure by means of short- as well as long-term interventions. Due to the drastic implications of the COVID-19 pandemic for persons whose livelihoods entail unsafe work conditions, and/or for financially insecure households, migrant workers are particularly at risk because they fall into both of those groups. ${ }^{283}$ Some of the recommendations States may be urged to consider in pursuance of their international obligations include ensuring that: migrant workers have access to information in language(s) comprehendible to them; mental healthcare services are made available to them on a non-discriminatory basis, are affordable for them, and are adapted to the skills used by them to overcome adversity in the past; they are consulted and encouraged to participate in the formulation of policies, programs, and plans pertaining to their health and well-being; and that swift action is undertaken in pursuance of the interdependence between the right to mental health and a wide array of other rights. ${ }^{284}$

\footnotetext{
${ }^{277}$ Maryam VIZHEH, Mostafa QORBANI, Seyed Masoud ARZAGHI, Salut MUHIDIN, Zohreh JAVANMARD, and Marzieh ESMAEILI, "The Mental Health of Healthcare Workers in the COVID-19 Pandemic: A Systematic Review" (2020) 19 Journal of Diabetes \& Metabolic Disorders 1967; Johannes H. DE KOCK, Helen Ann LATHAM, Stephen J. LESLIE, Mark GRINDLE, Sarah-Anne MUNOZ, Liz ELLIS, Rob POLSON, and Christopher M. O’MALLEY, "A Rapid Review of the Impact of COVID-19 on the Mental Health of Healthcare Workers: Implications for Supporting Psychological Well-Being” (2021) 21 BMC Public Health 104, online: BMC Public Health <https:// bmcpublichealth.biomedcentral.com/articles/10.1186/s12889-020-10070-3\#citeas>; Ashley Elizabeth MULLER, Elisabet Vivianne HAFSTAD, Jan Petere William HIMMELS, Geir SMEDSLUND, Signe FLOTTORP, Synne Øien STENSLAND, Stijn STROOBANTS, Stijn VAN DE VELDE, and Gunn Elisabeth VIST, "The Mental Health Impact of the COVID-19 Pandemic on Healthcare Workers, and Interventions to Help Them: A Rapid Systematic Review" (2020) 293 Psychiatry Research 113441.

${ }^{278}$ Vizheh, Qorbani, Arzaghi, Muhidin, Javanmard, and Esmaeili, supra note 283.

${ }^{279}$ Muller, Hafstad, Himmels, Smedslund, Flottorp, Stensland, Stroobants, Van de Velde, and Vist, supra note 283.

${ }^{280}$ De Kock, Latham, Leslie, Grindle, Munoz, Ellis, Polson, and O'Malley, supra note 283.

${ }^{281}$ Lene E. SØVOLD, John A. NASLUND, Antonis A. KOUSOULIS, Shekhar SAXENA, M. Walid QORONFLEH, Christoffel GROBLER, and Lars MÜNTER, "Prioritizing the Mental Health and Well-Being of Healthcare Workers: An Urgent Global Public Health Priority" (2021) Frontiers in Public Health, online: Frontiers in Public Health <https:/www.frontiersin.org/articles/10.3389/fpubh.2021.679397/full>.

${ }^{282}$ Mucci, Traversini, Giorgi, Tommasi, De Sio, and Arcangeli, supra note 230.

${ }^{283}$ WHO, "Promoting the Health of Migrant Workers in the WHO European Region During COVID-19" (6 November 2020), online: WHO <https://apps.who.int/iris/bitstream/handle/10665/336549/WHO-EURO-20201384-41134-55925-eng.pdf? sequence=1\&isAllowed $=y>$.

${ }^{284}$ International Organization of Migration, "Migrants and COVID-19: How to Take Care of Mental Health" (2020) online: International Organization of Migration <https://rosanjose.iom.int/site/en/blog/migrants-andcovid-19-how-take-care-mental-health>.
} 
While healthcare/frontline workers and migrant workers were discussed as instantiations in the case-study pertaining to India, there may be several more such groups in most societies across the world. For instance, persons institutionalized in State-run facilities, such as prisons and correctional homes, are yet another illustration. While some of the individuals admitted to such institutions may have pre-existing mental illnesses that may be exacerbated due to imprisonment, others may develop them over the period of their imprisonment due to enforced solitude and inadequate social interaction; the absence of meaningful activity or relationships; threats of violence; poor access to physical as well as mental healthcare services; and the perpetual threat of human rights violations, particularly torture and ill-treatment. ${ }^{285}$ During the COVID-19 pandemic, several of these causes have mutated to result in even more debilitating implications for the mental health of inmates, due to halted recreational and/or occupational activities, increased time spent on remand due to suspended trials, relatively scarce external social support, etc. ${ }^{286}$ States must recognize that they have a responsibility to "respect-protect-fulfil" the human rights of such individuals, more so during global crises when they are more vulnerable. ${ }^{287}$ Accordingly, States should ensure that they maintain a balance between the safeguarding measures taken by them to prevent the transmission of the virus and the implications of those measures on the mental health of the inmates in the short term, while investing in and ensuring access to mental healthcare services to the inmates in the long term. ${ }^{288}$ It is equally essential for treaty bodies monitoring States' compliance with a range of other human rights obligations, such as the prohibition against torture, to invest in developing jurisprudence that is cognizant of the intersectionality between the right to mental health and other rights.

Another such group meriting attention in this article is persons with severe pre-existing mental illnesses. Studies have evinced that such persons have been disproportionately disadvantaged during the pandemic due to the heightened effect of stressors; i.e., the duration of quarantines, fear of infection, disrupted access to healthcare, stigmatization, inadequate information, smaller social networks, and residential instability. ${ }^{289}$ In order to address these concerns, it is imperative for States to ensure that the healthcare system is resilient enough to withstand the burden of a global crisis and can continue to yield the necessary mental healthcare support. Moreover, alternatives such as telemedicine or consultations via video conferencing should be made available, and should be integrated into mental health policies and the organizational culture in order to mitigate concerns about privacy, safety, regulation, licensure, education etc. ${ }^{290}$ Further, States should ensure that the interlinkages between the right to information and the right to mental health are recognized. These individuals should be provided with accurate information about the virus, practices to be followed, available treatments, etc. in a manner that is tailored to their needs. ${ }^{291}$ Access

\footnotetext{
${ }^{285}$ International Committee of the Red Cross and WHO, "Information Sheet: Mental Health and Prisons", online: WHO <https://www.euro.who.int/_data/assets/pdf_file/0007/98989/WHO_ICRC_InfoSht_MNH_Prisons. pdf>; See also UN Doc. A/HRC/46/27 (2021), supra note 114 at para. 111.

${ }^{286}$ Thomas HEWSON, Andrew SHEPHERD, Jake HARD, and Jennifer SHAW, "Effects of the COVID-19 Pandemic on the Mental Health of Prisoners" (2020) 7(7) The Lancet Psychiatry 568.

${ }^{287}$ Michelle Bachelet, "Urgent Action Needed to Prevent COVID-19 'Rampaging Through Places of Detention”" (25 March 2020), online: OHCHR <https://www.ohchr.org/EN/NewsEvents/Pages/DisplayNews.aspx?NewsID= 25745>; Oroilidis, supra note 276.

${ }^{288}$ Hewson, Shepherd, Hard, and Shaw, supra note 292.

${ }^{289}$ Kai G. KAHL and Christoph U. CORRELL, "Management of Patients with Severe Mental Illness During the Coronavirus Disease 2019 Pandemic" (2020) 77 JAMA Psychiatry 977; Benjamin G. DRUSS, “Addressing the COVID-19 Pandemic in Populations with Serious Mental Illness" (2020) 77 JAMA Psychiatry 891.

${ }^{290} \mathrm{Kahl}$ and Correll, supra note 295.

${ }^{291}$ Druss, supra note 295.
} 
to such information is often determinative of whether these persons are accorded the right to make their own decisions and/or to freely exercise consent. This is of particular significance to persons with pre-existing mental illnesses who are residents of establishments, such as halfway homes or psychiatric facilities, due to their exposure to greater risk of ill-treatment due to limited contact with their loved ones during the pandemic. States should, therefore, ensure respect for their agency and criminalize practices which contravene the "freedoms" component of the right to mental health. It bears recognition that the groups of persons discussed by the authors in this part are by no means representative of an exhaustive set of such vulnerable groups globally, but are rather instantiations of such groups. It is also worth noting that the uniqueness of each national context lends itself to the definition of vulnerability and the emergence of marginalized groups in that particular context.

Thirdly, while the COVID-19 pandemic has disproportionately impacted certain groups of persons, the severe lockdowns, stringent quarantine policies, and travel bans imposed by States act as a threat to the mental health and well-being of all persons forced into self-isolation. While such measures may be necessitated by the nature of the pandemic, it is essential for States to balance the curtailments imposed on individuals' rights in pursuance of public health objectives with the content of the rights. Consequently, national lockdowns and quarantine policies applicable to symptomatic persons should be lawful and pursue a legitimate objective. They should also meet the thresholds of necessity and proportionality, be implemented for a limited duration of time, applied in a nondiscriminatory manner, be accompanied by a public notification, be reflective of respect for human dignity and integrity, and be subject to review. ${ }^{292}$ Similarly, travel bans should also be imposed in a lawful manner, for a legitimate purpose, and in a proportionate manner, particularly as such bans have historically had limited efficacy in preventing transmission. ${ }^{293}$ Moreover, alongside imposing mandatory restrictions as opposed to sweeping ones, States must ensure that any disruption still caused in accessing mental healthcare services must be mitigated through the provision of alternative services of comparable quality.

In order for the urgent call for global action to reap some of these desired results, international and domestic frameworks, stakeholders, and processes must work in tandem. Recognizing this, each of the recommendations proposed by the authors in this part, as well as in the foregoing part of this article, align with the international human rights framework guaranteeing the right to mental health. However, in order for these measures to be implemented effectively and yield results, it is imperative for the global authorities and norm-developers, identified in the first part of the article, to argue the non-derogable nature of this right, as well as monitor, report, and urge compliance by States. Equally essential is the role of these global bodies in directing advocacy efforts at government officials in those States constituting the international community, providing expertise and guidance for the introduction of measures which promote the human rights-based approach, and utilizing multilateral fora to draw attention to the issue and to urge international cooperation/assistance in a manner which is compliant with the rights-based approach.

\section{Conclusion}

As of August 2020, global estimates reflected that close to 1 billion people are living with mental disorders, and that one person dies by suicide every $40 \mathrm{s.}^{294}$ The COVID-19

\footnotetext{
${ }^{292}$ Human Rights Watch, supra note 14.

293 Ibid.

${ }^{294}$ WHO, “World Mental Health Day", supra note 80.
} 
pandemic, which has caused the fault-lines in the fulfilment of the right to mental health to be exposed and deepened, has showcased that mental health is one of the most neglected areas of public health. ${ }^{295}$ The incongruence between global norms and conformity in practice, prior to as well as amidst the pandemic, has compelled an urgent call for global action and magnified the need for engaged discourse on the importance of mental health as a human right. In pursuance, the authors have outlined the international rights-framework applicable to mental health in this article, endeavouring to highlight the non-derogable nature of the right and the continued obligations imposed on States. In particular, by drawing on India's experience, the authors have attempted to showcase that, while the implementation of the rights-framework at the domestic level has been deficient, such deficiencies are not reason enough for the promise and allure of human rights to be dismissed.

The COVID-19 pandemic has not only revealed and intensified these lacunae, but also provided the international community with new opportunities and reasons to ensure that the right is respected, protected, and fulfilled. It has, therefore, offered stakeholders the chance to pursue (much needed) radical shifts in recognizing and guaranteeing the right to mental health for all with renewed vigour. In pursuance, and by treating India as a core global reference, the authors have outlined recommendations for States to consider effectuating amidst, as well as in the aftermath of, the pandemic. It is hoped that the pandemic will mobilize the international community as well as individual stakeholders into action, and urge them towards the realization that there can be no health without mental health because human beings cannot be split into unrelated sections.

Acknowledgements. The authors are thankful to the anonymous peer reviewers for their insightful comments and to the editorial team at Asian Journal of International Law for their guidance. They are also grateful for the intellectual nourishment and support received from Oishik Sircar and Max Steuer.

Conflict of interest. The authors declare none.

${ }^{295}$ Ibid.

Cite this article: SANGHI S, JASWAL RT (2022). Of Promises and Discontents: Mapping India's Response to Guaranteeing the Right to Mental Health during the Covid-19 Pandemic. Asian Journal of International Law 12, 121-156. https://doi.org/10.1017/S2044251321000576 